\title{
Argümantasyon Temelli Deney Raporu Yazımının Fen Bilgisi Öğretmen Adaylarının Argüman Yapılarını Geliştirmelerine Etkisinin İncelenmesi*
}

\section{Examining the Effect on Development of Pre Science Teachers' Argument Structure of Writing the Argumentation Based Experiment Report}

\author{
Tufan INALTEKIN \\ Kafkas Üniversitesi, Eğitim Fakültesi, Matematik ve Fen Bilimleri Ĕ̆itimi Bölümü, Fen Bilgisi Eğitimi Anabilim Dalı \\ tufan.inaltekin@kafkas.edu.tr \\ Hakan AKÇAY \\ Yıldı Teknik Üniversitesi, Eğitim Fakültesi, Matematik ve Fen Bilimleri Eğitimi Bölümü, Fen Bilgisi Eğitimi Anabilim Dalı \\ hakcay@yildiz.edu.tr
}

Atıf: İnaltekin, T. \& Akçay, H. (2017). Argümantasyon Temelli Deney Raporu Yazımının Fen Bilgisi Öğretmen Adaylarının Argüman Yapılarını Geliştirmelerine Etkisinin İncelenmesi. E-Kafkas Eğitim Araştırmaları Dergisi, 4(3), 1-19.

$\ddot{\text { ozet }}$

Bu çalışmanın amacı, fen eğitiminin ayrılmaz bir parçası olan laboratuvar uygulamalarında argümantasyona dayalı deney raporu yazım anlayışını kullanan fen bilgisi öğretmen adaylarının süreç boyunca ortaya koydukları argümanların gelişimini incelemektir. Araştırma 2012-2013 güz yarıyılında Türkiye' deki bir devlet üniversitesinin fen bilgisi öğretmenliği programı 2. sınıfta öğrenim gören 46 öğretmen adayı ile yürütülmüştür. Araştırmanın deneysel tasarımı, örneklem grubunun zamana bağlı nasıl değişim gösterdiğini ortaya koyan zaman serisi deseni olarak belirlenmiştir. Bu araştırmanın verileri beş hafta boyunca Genel Biyoloji Laboratuvarı-I dersinde toplanmıştır. Araştırmanın veri toplama aracı, fen bilgisi öğretmen adaylarının laboratuvar derslerinde argümantasyon temelli hazırladıkları deney raporlarıdır. Fen bilgisi öğretmen adaylarının hazırlamıș oldukları deney raporları, Choi (2008) tarafından geliştirilmiş olan yazarak bilim öğrenme yaklaşımı puanlama ölçeği kullanılarak değerlendirilmiştir. Araştırmanın verileri SPSS 17 programı kullanılarak analiz edilmiştir. Analizden elde edilen bulgular, fen bilgisi öğretmen adaylarının beş hafta boyunca argümantasyon temelli hazırlamış oldukları deney raporlarındaki her bir argüman bileşeni puanında sürece dayalı anlamlı bir artış olduğunu göstermiştir. Bu araştırmanın sonucu, fen bilgisi öğretmen adaylarının lisans dönemi laboratuvar uygulamalarında argümantasyon temelli yazarak öğrenme anlayışını kullanmalarının, onların bilimi sorgulama ve anlama yolları geliştirmede etkili bir yaklaşım olduğunu göstermektedir.

Anahtar Kelimeler: Fen Öğretmen Adayları, Argümantasyon Tabanlı Bilim Öğrenme, Biyoloji Laboratuvarı, Fen Eğitimi

\begin{abstract}
The purpose of this study is to examine the development of the arguments presented throughout the process by the science teacher candidates using the sense of writing experiment report based on argumentation in the labaratory applications which is an integral part of science education. The survey was conducted with 46 teacher candidates studying in the second year of a science teacher education program in a state üniversity in the fall semester of 2012-2013 in Turkey. The experimental design of the study was designed as a time series design which shows how the sample group changes with time. The data of this study were collected in the General Biology Laboratory-I course for five weeks. The data collection tool of the research is the experimental reports prepared by the science teacher candidates on the basis of argumentation in laboratory lessons. The experimental reports prepared by science teacher candidates were evaluated using the scoring scale for science learning by writing approach developed by Choi (2008). The data from the study were analyzed using the SPSS 17 program. The findings from the analysis showed that there was a meaningful increase in the each argument component score based on the process in the argument-based experimental reports prepared by the science teacher candidates for five weeks. The result of this research shows that the science teacher candidates using the argumentation based sense of write and learn have an effective approach to develop methods for scientific inquiry and understanding.
\end{abstract}

Keywords: Preservice Science Teachers, Argumentation Based Science Learning, Biology Laboratory, Science Education

*Bu çalışma, International Conference on Education in Mathematics, Science \& Technology (ICEMST)-2017'de sözlü bildiri olarak sunulmuştur. 


\section{GíRiş}

Günümüzde birçok ülke gelecekleri için 21. yüzyılın beklentilerine cevap verecek yeterlilikte bireyler yetiştirme çabası içerisine girmiştir. Bundan otuz yıl önce eğitim açısından bireylerden beklenen bilgi ve davranış bugün için artık çok farklılaşmış bir boyuttadır. Uzay ve teknoloji çağının getirdiği bu değişimler bireylerin öğrenme becerilerininde değişmesi gerektiğine işaret etmektedir. Bu bağlamda düşünüldüğünde bireylerin eğitimindeki bu değişim çabasının kendisini en çok hissettirdiği alan belkide fen bilimleri alanı olmuştur. Bugün birçok ülke fen bilimleri alanında yüzyılın beklentilerine cevap verecek bireyleri yetiştirmek için bu alana çok daha ciddi yatırımlar yapmaya başlamışlardır. Eğitim üzerine kafa yoran birçok çevre, fen bilimleri alanında yetişecek bireylerden beklenen özellikleri, bilgiyi araştıran ve sorgulayan, karmaşık durumlara ilişkin eleştirel düşünen, problem çözme becerilerini kullanan ve yaratıcı fikirler sergileyebilen olarak tanımlamaktadır. Fen eğitimi alanındaki bu değişime ilişkin süreçlerden en önemlisi olarak, öğrencinin sorgulamaya dayalı düşünme yolları içerisinde bilgiyi anlamlı şekilde kazanması gösterilmektedir (Goldston ve diğ., 2010; Tseng ve diğ., 2013). $\mathrm{Bu}$ süreç içerisinde hem rehber olarak öğretmenin hemde bilgiyi yapılandıran olarak öğrencinin kullanacağ metotlar öğrenmenin anlamlandırılmasını sağlayan değişkenlerdir (Prain ve diğ., 2009; Furtak ve Alonzo, 2010; Rogers ve diğ., 2010; Dawson ve Venville, 2010). Bilginin anlamlı öğrenilmesine ilişkin fen eğitimi araştırmaları, öğrenme süreci içerisinde öğrenenin aktif olması ve elde edeceği bilgiyi kendi bilişsel öğrenmelerine dayalı olarak sorgulamasının önemi üzerinde durmaktadır (Haefner ve Zembal-Saul, 2004; Wee ve diğ., 2007; Prain ve Waldrip, 2010). Sorgulayarak öğrenme süreci, öğrencilerin gerçek dünya olaylarına ilişkin soruları cevaplarken bilimin araçlarını kullanmaları olarak tanımlanmaktadır (Hapgood ve Palincsar, 2006). Amerika Ulusal Fen Eğitimi Kurumu, 2000'li yıllardan beri fen eğitimine ilişkin standartları tanımlarken, öğrencilerin öğrenmede aktif katılımcılar olmaları ve bilimsel düşünce süreçlerini daha etkili kullanmaları için sorgulama temelli bir anlayışın gerekliliğini fen eğitiminin merkezi bileşeni olarak ifade etmişlerdir.

Fen eğitimi reform çalışmaları kapsamında anlamlı öğrenme üzerine söylemlere bakıldığında öğrencilerin bilimsel süreçler içerisinde meşgul olmaları gerektiğine vurgu yapmaktadır (Zembal-Saul, 2009). Öğrenmeyi anlamlı hale getirmenin bir yolu olarak sorgulama temelli fen eğitimi bilim insanları gibi düşünmeyi ve davranmayı gerektirmektedir. Bu anlayış fen konularının öğrenilmesinde geleneksel içerik öğretiminden farklı olarak konulara ilişkin problem durumlarını belirleme, olaylara ilişkin iddalar ortaya koyma ve çözüme ilişkin deliller bulma gibi bilimsel tartışma sürecine yön veren bir değişimi yansıtmalıdır (Martin ve Hand, 2009). Bilimsel tartışma, bilimsel sorgulama yapma yolunda merkezi bir özellik olarak tanımlanmaktadır (Osborne ve diğ., 2004). Sorgulamaya dayalı öğrenme sınıflarında, öğrenciler bilimsel düşünme yeteneklerini kullanma yoluyla bilgilerini anlamlandırma teşebbüsü içinde açıklamalar yapmaktadırlar. Ayrıca sorgulama süreçleriyle öğrenciler, üretilen yeni fikirlerle önceki fikirlerinin nasıl bütünleşeceğini keşfetme firsatı yakalamaktadırlar (Martin ve Hand, 2009).

Fen eğitiminde bilimsel sorgulama üzerine devam eden bu vurgu tartışmaya dayalı bilgi yapılandırması sürecini ön plana çıkarmaktadır. Bu perspektiften düşünüldüğünde bilimsel bilginin gelişmesi, sorgulamanın hedefleri ve bilimsel söylev (argümantasyon) uygulaması arasındaki ilişkinin güçlü bir şekilde bütünleştirilmesine bağlıdır (Zembal-Saul, 2009). Fen eğitiminde öğrenenin bilgiyi yapılandırmasına yönelik olarak uzun yıllar boyunca eğitimciler birçok yöntemi devreye sokmaya çalışmış ve pekçok uygulama süreci içerisinde bu yöntemlerin etkililiği üzerine fen eğitimini daha verimli hale getirme çabası içerisine girmişlerdir (Von Secker ve Lissitz, 1999; Norman ve diğ., 2001; Özmen, 2004; Schroeder ve diğ., 2007; Karamustafaoğlu, 2009). Fen eğitimi, bilimsel bir bağlam içerisinde anlamlı öğrenme argümanlarını formüle edebilme yeteneğini öğrencilere kazandırmalıdır. Bu bakımdan bilimsel davranışların sonuçları olarak biçimlenen argümantasyon, bilgi içeriğini anlamada epistemolojik yapının özel bir söylem türü ve bilişsel perspektifden kavramaların anlaşılmasına yardım edebilen öğretimsel bir süreçtir (Duschl ve diğ., 2007; Katchevich, Hofstein ve Mamlok-Naaman, 2011). Bricker ve Bell (2009), argümantasyonu, fenin epistemik bir uygulama merkezi ve bilimsel söylem içinde nasıl meşgul olunacağının öğrenilmesi olarak tanımlamıştır (Kuhn, 2010). Başka bir ifadeyle argümantasyon, fen eğitiminde bir bilgi inşası olarak düşünme, yazma ve açıklama yoluyla bireysel yâ da grup içinde sosyal aktiflik pozisyonunun alındığı bilimsel uygulama sürecidir (Sampson, 2009). Öğrenenlerin doğal dünya deneyimleri edinmelerinde anahtar bileşenlerden birisi olan argümantasyon, anlamlı bir tartışma sürecine ulaşmayı amaçlayan epistemolojik bütünlüktür (Kim ve Song, 2005). Son yıllarda argümantasyon temelli öğrenme uygulamaları, fen eğitiminde bilimsel bilgiyi öğrenenlerin anlamlı bir şekilde yapılandırmalarında etkili bir yöntem olarak yoğun bir şekilde tercih edilmiştir (Osborne ve diğ., 2004; Erduran ve diğ., 2006; Erduran, 2006; Zembal-Saul, 2009; Tippet, 2009; Hakyolu ve Ogan-Bekiroglu, 2011; Böttcher ve Meisert, 2011; Erduran \& Jime'nez-Aleixandre, 2011). Yine fen eğitimi alan yazında argümantasyon yönteminin öğretmen ve öğrencilerin bilgi anlayışlarını geliştirmede etkili bir öğrenme yolu olduğunu vurgulayan birçok çalışma mevcuttur (Osborne, Simon ve Erduran, 2002; Osborne, 2007; Kaya ve Kılıç, 2008 Ogunniyi ve Hewson, 2008; Berland ve Katherine L. McNeill, 2009; Hewson ve Ogunniyi, 2011). Fen eğitiminde argümantasyon çalışmaları, Toulman'ın 1958'deki hem öğretmenler hem de öğrenciler için kulanılabilen, bilimsel bir tartışmanın ana hatlarını ortaya koyduğu model üzerinden şekillenmiştir (Dawson ve Venville, 2010). Argümantasyonun yapısını birbirine bağlı öğeler açısından ele alan Toulmin'ın modeli, altı element içerir. Bu elementler; veri, delil, iddia, destekleyiciler, nitelendiriciler ve çürütücülerdir (Osborne ve diğ., 
2004). Veri; bir iddiayı desteklemek için başvurulan gerçeklerdir. Delil; iddia ve veri arasındaki ilişkiyi doğrulamakta kullanılan prensipler veya kurallardır. Destekleyiciler; bir delilin doğrulanmasını sağlayan varsayımların altında yatan temeldir. Nitelendiriciler; iddiayı doğrulayacak şartların altındaki durumlardır ve onlar iddialar üzerindeki sınırlamalarda yer alır. Çürütücüler; iddiayı doğrulamayacak şartların altındaki durumlardır. İddialar; tartı̧̧ma yoluyla kurulabilen değerlerin sonuçlarıdır (Tippet, 2009). Jimine'z-Aleixandre ve Erduran (2008), fen eğitiminde argümantasyonun potansiyeline ilşkin olarak şu hususları ifade etmişlerdir:

$\checkmark$ Öğrenciler için bilişsel ve metabilişsel süreçlere geçişi destekler.

$\checkmark$ İletişim becerilerinin gelişmesi ve özellikle eleştirel düşünmenin gelişimini destekler.

$\checkmark$ Bilimin dilini yazmak ve konuşmak için öğrecilere bilim okuryazarlı̆̆ının kazandırılmasını destekler.

$\checkmark$ Bilginin değerlendirilmesi için epistemik kriterlerin gelişimini ve çocuklara kültürel normlar kazandırma yoluyla sosyalleşmelerini destekler.

Amerika Ulusal Fen Eğitimi Standartları (NSES=National Science Education Standards) sorgulama temelli öğrenme oluşumları yoluyla, öğrencinin ne bildiğini ve nasıl daha fazla fikirlerle bu bilgilerini ilişkilendirebileceklerini belirten sözlü ve yazılı oluşumlar üzerine önemle vurgu yapmaktadır. Öğrencilerin bilimsel düşünme yolları içerisinde bilgiyi anlamlandırma yeteneklerini geliştirmeleri için sözel dili, yazmayı ve okumayı kullanmaları gerekmektedir (Hapgood ve Palincsar, 2006; Klein, 1999). Fen eğitiminde yazmaya dayalı firsatlar, fen kavramalarını anlamak için öğrencilere imkân veren bir kaynak olarak kullanılmaktadır. Günümüzde feni yazarak ve konuşarak öğrenmenin önemi fen eğitimi araştırmalarında giderek artan bir ilgi haline gelmiştir (Porter ve Masıngıla, 2000; Keys, 1999; Yore ve diğ., 2003; Hand ve diğ., 2007; Armstrong ve diğ., 2008; Nückles ve diğ., 2010; Nam ve di ̌̆., 2011; Peker ve Wallace, 2011; Tomas ve Ritchie, 2012). Bu çalışmalar; öğrenme başarısının yazma yoluyla nasıl ilerlediğini, farklı yazma uygulamalarıyla ilgili bilişsel süreçlerin tanımlanmasını ve öğrenci öğrenmeleri üzerinde farklı yazma etkinliklerinin etkisini içermektedir (Mason, 1998; Klein, 2000; Levin ve Wagner, 2006; Klein, 2006; Hand ve diğ., 2007; Mateos ve diğ., 2008; Hand ve diğ., 2009; Günel ve diğ., 2009; Papadopoulos ve diğ., 2011; Mc Dermott ve Hand, 2012).

Eğitimde kullanılan dil hem bilimin üretilmesinde hem de aktarılmasında merkezi bir rol oynamaktadır. Bilimsel bilginin yapılandırılmasında bir yol olarak fen derslerinde yazma aktivitelerinin kullanılması, öğrenenlerin kişisel olarak aktif bir sürece dahil olmaları firsatını sunan eşsiz bir oluşumdur (Choi ve diğ., 2010). Fen eğitiminde 1970 'in ortalarından beri konuların içeriğinin anlamlı bir şekilde öğrenilmesinde yazma işleminin nasıl katkı sağlayıp sağlamadığı araştırma sorusu olarak sürekli karşımıza çıkmaktadır. Rivard and Straw (2000: p.569) eğitimde yazının önemini şöyle belirtmişlerdir; "Bir öğrenme enstrümanı olarak yazının kullanılması bilginin kişisel olarak yapılandırılmasını üstlenmektir." Carlson (2007), "Öğrencilere bilimsel olarak yazmayı ögretmek, onlara bilimsel olarak düşünmeyi ögretmektir" (p.53) şeklinde öğrenme sürecinde anlamlı bilgi yapıları oluşturmak için öğrencinin düşüncelerini yazıya çeşitli şekillerde dökmesinin önemini vurgulamaktadır. Daha da önemlisi yazmaya dayalı öğrenme öğrenenlerin bilgi yapılarına ilişsin yaratıcı, analitik ve eleştirel düşünebilme becerilerini ortaya koyan yansıtıcı ögrenme aktiviteleridir (D'Avanzo, 2003). Bazı araştırmalar, yazmaya dayalı etkinliklerin ne kadar erken yaşlarda öğrenme süreçlerine dahil edilirse öğrencinin bilgilerini yansıtmada o kadar etkili olacağını belirtmektedirler (Kieft ve diğ., 2006; Hohenshell ve Hand, 2006; Choi ve diğ., 2010). Mason ve Boscolo (2000) göre eğer bir öğrenme aracı olarak öğrencilerin yazmayı kullanmalarını istiyorsak, o zaman onlara düşünme ve muhakeme etme firsatı vermeli ve öğrenmelerini istediğimiz konuya ilişkin kendi anlatım dillerinde düşünebilme imkânı tanımalıyız. Fen derslerinde yazarak öğrenme tekniklerinin kullanılması daha çok düşünmeyi ve iletişim yeteneğini ilerletmede kullanılmaktadır. Bunun yanında öğrencilerin bilgiyi keşfetme, bilim okuyazarlığını geliştirme, içerik bilgisini ilerletme, bilginin sergilenmesi, inanışlar üzerine yansıtma ve düşünceleri organize etmeyi sağlayan bir oluşum olarakta üzerinde önemle durulmaktadır (Keys, 1999; Levin ve Wagner, 2006; Hand ve diğ., 2007; Baker ve diğ., 2008). Ortaokul fen eğitiminde yazmaya dayalı aktiviteler, öğrencilerin bilim okuryazarlıklarının gelişmesinde, meta bilişsel ilerlemede ve fene ilişkin düşünme yeteneklerini geliştirmede pozitif bir tema olarak karşımıza çıkmaktadır (Hand ve Prain, 2001). Fen eğitiminde bilginin kişisel olarak yapılandırılmasında ve öğrenenin zihinsel dünyasındaki soyut oluşumların sergilenmesinde yazarak öğrenme çalışmaları önemli bir yer tutmaktadır (Yore ve diğ, 2003; Hohenshell ve Hand, 2006). Klein (2006), öğrencilerin bilimsel bilgiyi anlamlı yapılar içinde açıklamaya ihtiyaç duyduklarını ve bilimsel düşüncelerini kendi ifadeleriyle açıklama ihtiyacı hissettiklerini belirtmektedir. Öğrenciler bilişsel yapılandırmada, dil ve düşüncenin bir bütünlük içinde geliştiği süreçlere ve kendi zihinlerindeki sözcüklerle ifade etmelerine imkân sağlayan oluşumların desteklenmesine ihtiyaç duymaktadırlar (Hand ve diğ., 2009). Feni öğrenmede argumantasyon sürecini, yazma ve söylem üzerine bir teorik bütünleşme olarak sunan Argümantasyon Tabanlı Bilim Öğrenme $(A T B O ̈)$ yaklaşımı, öğrencileri bilimsel kavramları öğrenirken ezberlemenin ötesinde kanıta dayalı bir tartışma süreci inşa ederek, daha kapsamlı anlamlandırmalara yöneltmektedir (Takao ve Kelly, 2003). ATBÖ yaklaşımı, öğrencilerin sorular sorduğu, iddialarını tanımladığı, gözlemlerini kayıt ettiği, delillerini sağladığı ve fen kavramlarına ilişkin anlayışları üzerine yansıtmada bulunmalarına imkan veren bir öğrenme sürecini temsil etmektedir (Poock ve diğ., 2007). Keys ve diğ., (1999), ATBÖ’yü fen içeriğini öğrencilerin anlamasına yardım eden, veriler hakkında öğrencileri düşünmeye sevk eden ve uygulamalara klavuzluk eden bir yaklaşım olarak tanımlamışlardır. Ayrıca bilimsel sorgulama içersine argümantasyonu katarak, öğrenme içinde dil kullanmanın 
önemini tanımlayan bir taslak olarak ATBÖ’yü biçimlendirmişlerdir. АTBÖ yaklaşımı, aktiviteler yoluyla öğrencilere kılavuzluk eden tartışmacı ve sorgulayıcı fen öğretiminde bilimin doğasını yansıtan, hem öğretmen hem öğrenci şablonuna dayalı yazma aktivitelerini içermektedir (Akkus ve diğ., 2007). Orijinal Adı "Science Writing Heuristic" ve Türkçe'ye cevirisi "Argümantasyon Tabanlı Bilim Öğrenme" yaklaşamı olan ATBÖ, sorgulamaya dayalı fen öğretimde, dili etkin bir şekilde kullanarak bunu yazıya ve konuşmaya dökme sürecini ifade etmektedir (Kıngır ve diğ., 2011). Bilgiyi anlamlı öğrenmede, bilimsel tartışma ve okuma-yazma gibi dil etkinliklerini içeren temel dinamikler üzerine inşa edilen öğrenme yaklaşımıdır. ATBÖ yaklaşımı, sözlü ve yazılı tartışmayı kullanma yoluyla laboratuvar aktivitelerinde, fen öğrenmeyi kolaylaştırmak için geliştirilen sorgulama dayalı bir argümantasyon uygulamasıdır (Keys ve diğ., 1999). Öğrenci ve öğretmen şablonu olmak üzere iki şablon içermektedir (Tablo 1). Öğrenci şablonu, laboratuvar araştırmaları hakkında öğrencilerin düşüncelerini biçimlendiren yarı yapılandırılmış yazım formudur. $\mathrm{Bu}$ şablon, öğrencilerin bilimsel araştırmaları anlamlandırmalarına ilişkin kendi müzakerelerini kolaylaştıran yazma aktivitlerini içermektedir. Öğretmen şablonu, öğrencilerin bilimsel sorgulama süreçlerinde meşgul olduğu grup ve sınıf müzakerelerini kolaylaştırmaya rahberlik eden oluşumları ifade eder (Nam, Choi ve Hand, 2011; Günel ve diğ., 2012).

Tablo 1.

ATBÖ yaklaşımı öğretmen ve öğrenci şablonları

\begin{tabular}{|c|c|}
\hline Öğretmen Şablonu & Öğrenci Şablonu \\
\hline $\begin{array}{l}\text { Kavram haritası yoluyla ön bilgilerin ortaya } \\
\text { çıarılması }\end{array}$ & > Başlangıç Düşünceleri-Sorularım Nelerdir? \\
\hline $\begin{array}{l}\text { İnformal yazma, gözlem yapma, beyin firtınası ve soru } \\
\text { sorma tekniklerinin kullanıldığı laboratuvar öncesi } \\
\text { etkinliklerin yapılması. }\end{array}$ & $>$ Testler-Ne yaptım? \\
\hline$>$ Laboratuvar etkinliklerine katılım & $>$ Gözlemler-Ne gördüm? \\
\hline $\begin{array}{l}\text { Müzakere Fazı-Laboratuvar etkinliklerinde kişisel } \\
\text { yazma faliyetlerinin yapılması }\end{array}$ & $>$ İddialar-Ne iddia edebilirim? \\
\hline $\begin{array}{l}\text { Müzakere Fazı- Küçük gruplarda gözlemlerden elde } \\
\text { edilen verilerin yorumlarının paylaşımı ve } \\
\text { kıyaslanması }\end{array}$ & $\begin{array}{l}\text { Kanıt-Nasıl anladım? Niçin bu iddialarda } \\
\text { bulunuyorum? }\end{array}$ \\
\hline $\begin{array}{l}\text { Müzakere Fazı-Düşüncelerin Kitap yâda diğer } \\
\text { kaynaklar ile karşılaştırılması }\end{array}$ & $\begin{array}{l}\text { Okuma- Benim düşüncelerim başka } \\
\text { düşüncelerle nasıl karşıştırılır? }\end{array}$ \\
\hline $\begin{array}{l}\text { Müzakere Fazı- Bireysel yansıma ve yazma } \\
\text { faliyetlerinin yapılması }\end{array}$ & > Yansıma-Düşüncelerim nasıl değişti? \\
\hline $\begin{array}{l}\text { Kavram haritası yoluyla öğretim sonunda } \\
\text { öğrenilenlerin ortaya çıarılması }\end{array}$ & \\
\hline
\end{tabular}

ATBÖ yaklaşımında öğrencilere deneyi nasıl yapacakları açıkça söylenmez, bunun yerine öğrenciler aktif olarak soruları cevaplama içinde olurlar. Öğrenciler için ATBÖ şablonu, bilimsel sorgulama içinde bilgiyi yapılandırmada öğrencilere yardım eden bir araçtır. Geleneksel laboaratuvar raporlarının içerdiği amaç, metod, gözlem, sonuçlar ve değerlendirme gibi bölümlerin olmamasıyla farklılaşır. Bu bakımdan ATBÖ yaklaşımı, bilimsel sorgulama içinde ortaya çıkarılan öğrenci yazılarındaki argümanların analiz edilebilmesi imkanını sunar (Choi ve diğ., 2010). ATBÖ yaklaşımının bileşenleri, yansıtıcı düşünme ve yazmanın elementlerini içeren bir bütünlüğe sahiptir (Akkuş ve diğ., 2007; Martin ve Hand, 2009; Nam, Choi ve Hand, 2010; Cavagnetto ve diğ., 2010; Kingir ve diğ., 2011; Chen ve diğ., 2016). Hand ve diğ. (2004) çalışmalarında, yedinci sınıf fen derslerinde ATBÖ yakalaşımını kullanarak öğrencilerin laboratuvar aktivitelerindeki gelişimlerini incelenmişlerdir. Araştırmaya katılan öğrenciler laboratuvar raporlarını ATBÖ öğrenci şablonu ve geleneksel formatta hazırlamışlardır. Araştırma sonuçları geleneksel yaklaşımla, ATBÖ yaklaşımının uygulandığı gruplar arasında performans düzeyleri bakımından, ATBÖ yaklaşımı lehine anlamlı bir fark olduğunu göstermiştir. Öğrencilerle yapılan görüşmeler sonucu, feni sorgulama anlayışlarındaki gelişim ve aktiviteleri tamamlamak için ihtiyaç duyulan bilişsel ve metabilişsel süreçlerin farkında olunmasına ilişkin de önemli farklılıklar olduğu görülmüştür. Laboratuvar aktiviteleri boyunca öğrenciler, veri toplar, gözlem yapar, notları kayda geçer ve aktivitelerinin sonuçları hakkında bilimsel geçerlilikler ortaya koyarlar (Akçay, Hand ve Norton-Meier, 2010). Anlamlı bilgi yapıları oluşturmaya firsat veren eşsiz bir öğrenme çevresi olarak fen laboratuvarının eğitimsel etkileri, pek çok çalışmada vurgulanmıştır (Hofstein ve diğ., 1996; Sharma ve Anderson, 2009; Morgil ve diğ., 2009; Koray ve diğ., 2007; Yeşilyurt, 2006; Choi ve diğ., 2013; Aslan ve Tekin, 2015). Günümüzde fen eğitiminin hedeflerinden biri bilimsel bağlam içinde argümantasyonun yapılandırılmasına ilişkin oluşumları öğrencilere sağlamaktır. Son yıllarda pek çok çalışma fen eğitiminde argümantasyonun yapılandırılması üzerine yürütülmüştür. Fakat bu araştırmaların sadece birkaçı laboratuvar uygulamalarıyla ilişkilendirilmiş̧ir (Kim ve Song, 2006; Hohenshell and Hand 2006; Poock ve diğ., 2007; Peker ve Wallace, 2011; Walker, 2011; Katchevich ve diğ., 2011). Bu bağlamda araştırmamızın temel amacı, fen bilgisi öğretmen adaylarının laboratuvar derslerinde argümantasyona dayalı yazdıkları deney raporlarında süreç boyunca anlamlı bir argüman gelişiminin olup olmadığının incelenmesidir. 
Geleneksel fen laboratuvarı uygulamalarında öğrenciler, genel olarak öğretmenin araştırma sürecine yön vermesini takip ederek bilimsel düşünceler oluşturmaktadırlar. Son yıllarda fen eğitimi üzerine yapılan araştırmalar, öğrencilerin öğretimin tüm oluşumlarına aktif olarak dâhil edilmeleri gerektiğini ifade etmektedir. Fen derslerinde öğrenilen teorik bilginin somutlaştırılmasında eşsiz firsatlar sunan laboratuvar uygulamaları, öğrencinin bilimsel düşüncesini gözleme dayalı anlamlandırmasında çok önemli bir süreçtir. Fen laboratuvarlarındaki deney raporları öğrencilerin bilimsel bilgi yapılarına ilişkin düşüncelerini yansıtmalarında önemli bir köprü görevi yapmaktadır. Buradan yola çıkarak bu çalışmanın problemini "Laboratuvar uygulamalarında argumantasyona dayalı söylem ve yazı üzerine rapor yazımının fen bilgisi öğretmen adaylarının süreç boyunca oluşturdukları argüman yapılarının gelişimine etkisi nasıldır?” sorusu oluşturmaktadır.

\section{YÖNTEM}

\section{Araştırmanın Deseni}

Araştırmanın deseni, deneysel araştırma desenlerinden zaman serili desendir. Bu tür araştırma desenleri uzunlamasına yapılmaktadır. Bu tür araştırmalarda zaman önemli bir değişken olarak karşımıza çıkmaktadır (Sönmez ve Alacapınar, 2014). Zamana yayılan tasarımlarda iki veya daha fazla değişik zamanda veri toplanmaktadır. Zamana yayılan tasarımlar diğer tasarımlara göre daha karmaşık ve pahalı olmasına rağmen, üzerinde çalışılan konunun zaman içerisinde nasıl değiştiğini gözleme açısından daha güçlüdür (Neuman, 2000; Durna, 2010). Bu araştırmada 46 fen bilgisi öğretmen adayından oluşan tek gruplu bir zaman serisi deseni kullanılmıştır. Araştırmada argümantasyona dayalı yazılan deney raporlarının zaman içerisinde fen bilgisi öğretmen adaylarının üretmiş olduğu argümanların niteliğini geliştirmedeki etkisine bakılmıştır.

\section{Çalışma Grubu}

$\mathrm{Bu}$ araştırmanın çalışma grubunu, 2012-2013 öğretim yılı güz yarıyılında Türkiye'deki bir devlet üniversitesinin fen bilgisi öğretmenliği programı 2. sınıfinda öğrenim gören 46 öğretmen adayı oluşturmaktadır. Araştırmaya katılan öğretmen adaylarının \%54,3’ü (N:25) erkek, \%45,7’i (N:21) bayandır.

\section{Uygulama}

$\mathrm{Bu}$ araştırma Fen bilgisi öğretmenliği lisans programı 2. Sınıfta okutulmakta olan Genel Biyoloji Laboratuvarı-I dersinde yürütülmüştür. Deneysel uygulama konuları olarak; Farklı Hücre Yapıları, Hücre Bölünmeleri, Kan Hücreleri, Organik Madde Tayini ve DNA İzolasyonu olmak üzere beş uygulama konusu seçilmiştir. Bu araştırma sürecine başlamadan önce, uygulama grubundaki öğretmen adaylarına ATBÖ yaklaşımı hakkında üç ders saati ve ATBÖ yaklaşımına dayalı deney raporu yazımı konusunda da iki ders saati olmak üzere toplam beş ders saati araştırmacılar tarafindan seminer verilmiştir. Ayrıca öğretmen adaylarına ATBÖ öğrenci şablonuna dayalı deney raporu yazımı kapsamında literatürden iki adet örnek makale incelemeleri için verilmiştir. Yine öğretmen adaylarına örnek argümantasyona dayalı deney raporu yazım formları dağıtılarak uygulama öncesinde bu formlar üzerinde inceleme yapmaları sağlanmıştır. Fen bilgisi öğretmen adayları Biyoloji Laboratuvarı-I derslerinde dörderli gruplar halinde biyoloji deneyleri üzerinde çalışmışlardır. Bunun yanında ise her öğretmen adayı bireysel deney raporu hazırlamıştır. Araştırmacılar, öğretmen adaylarının her deney çalışmasına ilişkin raporlarda yazdıkları argümanların niteliğini, bir sonraki uygulamada iyileştirmeleri konusunda uygun ipuçlarıyla desteklemişlerdir. Fen bilgisi öğretmen adayları beş hafta boyunca Genel Biyoloji Laboratuvart$I$ dersi bitiminde hazırladıkları deney raporlarını araştırmacılara teslim etmişlerdir.

\section{Verilerin Toplanmast}

Araştırma verilerinin toplanmasında, Argümantasyon Temelli Bilim Öğrenme (ATBÖ) yaklaşımlarında sıklıkla kullanılan "Öğrenci Deney Raporu Yazım Formu” kullanılmıştır (Choi, 2008). Bu deney raporu yazım formu öğrencinin yapacağı deneyle ilgili merak ettiği konuları bir soruyla başlatan ve argümantasyon sürecini bir bütünlük içinde iddia, delil ve yansıma durumlarıyla biçimlendirdiği yapıyı ifade etmektedir (Kıngır ve diğ., 2011). Araştırmanın verileri fen bilgisi öğretmenliği 2. sınıf Genel Biyoloji Laboratuvart-I dersinde beş haftalık bir uygulama süreci boyunca toplanmıştır. 


\section{Verilerin Analizi}

Verilerin analizinde, ilk iş olarak öğrenci deney raporlarından elde edilen nitel veriler puanlanarak nicel verilere dönüştürülmüştür. Bu amaçla Choi (2008) tarafindan geliştirilmiş olan puanlama ölçeği kullanılmıştır (Ek1). Bu puanlama ölçeği argümantasyonun bileşenleri ve bu bileşenler arasındaki anlamlı bir bütünlüğü vurgulayan sekiz ayrı yapıyı içermektedir. Puanlama ölçeğinde her boyut belirli sayıda ve nitelikte özelliği temsil etmesine göre 1 ile 5 puan arasında değerlendirmeye imkân vermektedir. Örneğin, öğrencilerin deney raporlarında ortaya koyduğu araştırma sorusu test etmeye imkân vermiyorsa bu özellik ölçekte 1 puanla değerlendirilmektedir. Eğer öğrencinin ortaya koyduğu soru fikirlerine yön vermede, uygulamanın özünü yakalamada etkili ve test edilebilme imkânı veriyorsa 5 puanla değerlendirilmektedir. Nitel verilerin puanlanırken her iki araştırmacı tarafindan da puanlama yapılarak, analiz iç tutarlılığııın sağlanması amaçlanmıştır. Buna göre, ATBÖ yaklaşımına dayalı yazılan deney raporlarındaki her bir bileşen için ortalama iç tutarlılık korelasyon değerleri şu şekilde hesaplanmıştır; Soru (.78), iddia (.72), delil (.69), soru-iddia ilişkisi (.75), iddia-delil ilişkisi (.78), yansıma (.81), bütüncül düşünce (.74) olarak hesaplanmıştır. Araştırmada nitel verilerin nicel verilere dönüştürülmesinden elde edilen puanlar SPSS 17. programında analiz edilmiştir.

\section{BULGULAR}

Araştırmanın bu bölümünde, fen bilgisi öğretmenliği lisans programı Biyoloji Laboratuvarı-I dersinde beş hafatalık uygulama süresi boyunca hazırlanan argumantasyon temelli öğrenci deney raporlarındaki argüman gelişimine ilişkin analiz bulguları sunulmuştur.

Tablo 2.

Argümantasyon temelli hazırlanan deney raporlarındaki soru, iddia ve delil bileşenlerinin gelişimi analiz sonuçları

\begin{tabular}{cccccccc}
\hline \multirow{2}{*}{$\begin{array}{c}\text { Uygulama } \\
\text { No }\end{array}$} & $\mathrm{N}$ & \multicolumn{2}{c}{ Soru } & \multicolumn{2}{c}{ İddia } & \multicolumn{2}{c}{ Delil } \\
\cline { 3 - 8 } & & $\mathrm{X}$ & $\mathrm{S} . \mathrm{S}$ & $\mathrm{X}$ & $\mathrm{S} . \mathrm{S}$ & $\mathrm{X}$ & $\mathrm{S} . \mathrm{S}$ \\
\hline 1 & 46 & 1,71 &, 65 & 1,17 &, 46 & 1,19 &, 38 \\
2 & 46 & 2,00 &, 56 & 1,73 &, 44 & 1,69 &, 46 \\
3 & 46 & 2,19 &, 42 & 2,36 &, 48 & 2,17 &, 52 \\
4 & 46 & 2,58 &, 49 & 2,86 &, 45 & 2,78 &, 41 \\
5 & 46 & 3,21 &, 41 & 3,32 &, 47 & 3,34 &, 48 \\
\hline
\end{tabular}

Tablo 2'de fen bilgisi öğretmen adaylarının АTBÖ yaklaşımına dayalı olarak beş haftalık uygulama konuları bağlamında yazmış oldukları deney raporlarındaki argumantasyon bileşenlerinden soru, iddia ve delil bileşenlerine iliş̧in gelişim durumları verilmiştir. Buna göre öğretmen adaylarının deney raporlarından soru bileşeni için, sırasıyla "Farklı Hücre Yaplları" X=1,71, "Organik Madde Tayini" X=2,0, "Hücre Bölünmeleri" $\mathrm{X}=2,19$, "Kan Hücreleri" $\mathrm{X}=2,58$ ve "DNA İzolasyonu" $\mathrm{X}=3,21$ ortalama puanlar aldıkları tespit edilmiştir. İddia bileşeni için, "Farklı Hücre Yapıları" $\mathrm{X}=1,17$, "Organik Madde Tayini" $\mathrm{X}=1,73$, "Hücre Bölünmeleri" $\mathrm{X}=2,36$, "Kan Hücreleri" X=2,86 ve "DNA İzolasyonu” $\mathrm{X}=3,32$ ortalama puanlar aldıkları tespit edilmiştir. Delil bileşeni için, "Farklı Hücre Yapıları" X=1,19, "Organik Madde Tayini" X=1,69, "Hücre Bölünmeleri” X=2,17, "Kan Hücreleri" $\mathrm{X}=2,78$ ve "DNA İzolasyonu” $\mathrm{X}=3,34$ ortalama puanlar aldıkları tespit edilmiştir. Bu bulgulara dayalı olarak öğretmen adaylarının üretmiş oldukları argüman yapıları olan sorular, iddialar ve delillerin kalitesi ve bilimsel geçerliliği beş haftalık sürede önemli bir gelişim göstermiştir. Aşă̆ı̆da verilmiş olan alıntılar öğretmen adaylarının deney raporları puanlama ölçeğine göre değerledirildiğinde düşük ve yüksek kalitede argüman yapıları olarak belirlenmiş örnekleri ifade etmektedir:

\section{Etkinlik 1(Farklı Hücre Yapıları) için üretilen soru yapıları;}

"Hayvan ve bitki hücresi arasındaki farki gözlemlerle bulabilir miyiz?”(K11)

“Kitaplarda gördü̈̆̈̈m hayvan ve bitki hücresi resimlerini gözlemleyebilir miyim?”(E14)

Yukarıdaki soru yapılarına bakıldığında, araştırmacılar puanlama cetveline göre her iki soru yapısını da 1 . düzey argüman olarak değerlendirmişlerdir. Burada araştırmacıların her ikiside bu soru yapılarını kapalı uçlu ve düşük kalitede olduğuna karar vermişlerdir.

“Bitki ve Hayvan hücresinin yapısal özelliklerini nasll ayırt edebiliriz?”(E13)

"Farklı hücrelerin sinıflandırmasını yapabilecek özellikleri nasıl tespit edebiliriz?”(K19) 
Yukarıdaki soru yapılarına bakıldığında, araştırmacılar puanlama cetveline göre (E13)'ün sorusunu 4. düzey, (K19)'un sorusunu ise 5. düzey argüman olarak değerlendirmişlerdir. Burada araştırmacılar bu soru yapılarını test edilebilir ve araştırmanın özünü yakalayan soru yapıları olarak değerlendirmişlerdir.

\section{Etkinlik 2 (Organik Madde Tayini) için üretilen soru yapıları;}

“Ayıraçlar yardımiyla besinlerdeki organik maddeleri nasıl ayltt edebiliriz?”(E5)

"Hangi ayıraçlar hangi malzemelerle ne renk verir?"(K2O)

Yukarıdaki soru yapılarına bakıldığında, araştırmacılar puanlama cetveline göre her iki soru yapısını da 1. düzey argüman olarak değerlendirmişlerdir. Burada araştırmacıların her ikiside bu soru yapılarını araştırmanın özünü yakalamada düşük kalitede olduğuna karar vermişlerdir.

"Bir organik maddenin verilen örnekte varlı̆̆ın tespit etmek için sadece ayıraçlarla ilişkisi bulunması yeterli midir?"(E11)

"Ayıraçlar karakteristik organik maddede neden renk değiştirir?"(K8)

Yukarıdaki soru yapılarına bakıldığında, araştırmacılar puanlama cetveline göre (E11)'in sorusunu 5. düzey, (K8)'in sorusunu ise 4. düzey argüman olarak değerlendirmiş̧lerdir. Burada araştırmacıların her ikiside bu soru yapılarını açık uçlu ve araştırmanın özünü yakalayan soru yapıları olarak değerlendirmişlerdir.

\section{Etkinlik 3 (Hücre Bölünmeleri) için üretilen soru yapıları;}

“Mitoz bölünmede başlangıca göre kaç hücre oluşur?”(K20)

“Mitoz ve Mayoz bölünme arasindaki farklar nelerdir?”(K9)

Yukarıdaki soru yapılarına bakıldığında, araştırmacılar puanlama cetveline göre her iki soru yapısını da 2. düzey argüman olarak değerlendirmiş̧lerdir. Burada araştırmacıların her ikiside bu soru yapılarını araştırmanın özünü yakalamada düşük kalitede soru yapıları olduğuna karar vermişlerdir.

"Bir hücrede bölünme sonunda oluşan yeni hücre kalttsal olarak temel hücreyle aynı özelliklere mi sahip olur?"(E21)

“Tek hücreli ve çok hücreli organizmalarda hücre bölünmesinin evreleri aynı mıdır?”(K16)

Yukarıdaki soru yapılarına bakıldığında, araştırmacılar puanlama cetveline göre (E21)'in sorusunu 5. düzey, (K16)'nın sorusunu ise 4. düzey argüman olarak değerlendirmişlerdir. Burada araştırmacıların her ikiside bu soru yapılarını araştırmanın özünü yakalayan yüksek kalitede soru yapıları olarak değerlendirmişlerdir.

\section{Etkinlik 4 (Kan Hücreleri) için üretilen soru yapıları;}

"Kan hücrelerinin insan vücudundaki görevleri nelerdir?”(E1)

“İnsan vücudunda ki kan hücrelerinin yapısal farklllıklainı nasıl tespit edebiliriz?”(E19)

Yukarıdaki soru yapılarına bakıldığında, araştırmacılar puanlama cetveline göre her iki soru yapısını da 1. düzey argüman olarak değerlendirmişlerdir. Burada araştırmacıların her ikiside bu soru yapılarını araştırmanın özünü yakalamada düşük kalitede soru yapıları olarak değerlendirmişlerdir.

"Vücudumuzdaki kan hücreleri saylsal olarak neden biribirinden farkllıdır?(K10)

“Ömürlerini tamamlayan kan hücreleri nasl yok olmaktadırlar?”(K20)

Yukarıdaki soru yapılarına bakıldığında, araştırmacılar puanlama cetveline göre (K10)'un sorusunu 5. Düzey, $(K 20)^{\prime}$ 'nin sorusunu ise 4. Düzey argüman olarak değerlendirmişlerdir. Burada araştırmacıların her ikiside bu soru yapılarını araştırmanın özünü yakalayan yüksek kalitede soru yapıları olarak değerlendirmişlerdir.

\section{Etkinlik 5 (DNA İzolasyonu) için üretilen soru yapıları;}

“DNA'yl gözlemlemek için hangi işlemleri yapmallyız?”(E4)

“Bir bitki hücresinin DNA 'sinı nasıl gözlemleyebiliriz?”(E11)

Yukarıdaki soru yapılarına bakıldığında, araştırmacılar puanlama cetveline göre her iki soru yapısını da 1 . düzey argüman olarak değerlendirmişlerdir. Burada araştırmacıların her ikiside bu soru yapılarını araştırmanın özünü yakalamada düşük kalitede soru yapıları olarak değerlendirmişlerdir.

"Canlıların kalıtsal özelliğini taşıyan DNA'yl biyokimyasal yöntemlerle nasıl ipliksi yapıya aytrabiliriz?”(K14) 
"Canlı hücrelerinde hücre duvarlarının yıkılarak, DNA- protein kompleksinin çözülmesi nasıl sağlanabilir?(E3)

Yukarıdaki soru yapılarına bakıldığında, araştırmacılar puanlama cetveline göre (K14)'ün sorusunu 4. Düzey, (E3)'ün sorusunu ise 5. Düzey argüman olarak değerlendirmişlerdir. Burada araştırmacıların her ikiside bu soru yapılarını araştırmanın özünü yakalayan yüksek kalitede soru yapıları olarak değerlendirmişlerdir.

\section{Etkinlik 5 (DNA İzolasyonu) için üretilen iddia yapıları;}

“Soğan zarını belli işlemlerden geçirerek DNA'yı iplikçikler halinde gözlemleyebiliriz. ”(E6) vardır. ”(E7)

“Bir canlı hücresindeki DNA'nın yapsındaki proteinleri ayırmak için güçlü enzimlere ihtiyacımız

Yukarıdaki iddia yapılarına bakıldığında, araştırmacılar puanlama cetveline göre (E7)'nin iddasını 4. Düzey, (E6)'nın iddasını ise 1. Düzey argüman olarak değerlendirmişlerdir. Burada araştırmacıların her ikiside (E6)'nın üretmiş olduğu iddiayı hiçbir veri ve gözleme dayanmaz yapı olarak değerlendirmişlerdir. (E7)'nin üretmiş olduğu iddia araştırmanın özünü yakalamada önemli ve yeterlidir.

\section{Etkinlik 5 (DNA İolasyonu) için üretilen Deliller;}

"Kimyasal bir reaksiyon için optimum sıcaklık önemlidir ve bu yüzden DNA yapısını protein yapısından ayırmak için ısıtma işlemine tabi tuttum. DNA yı saf iplikçikler halinde gözlemlemek için hidroliz şarttır. Fiziksel olarak ısitılan hücrenin bunun yanında kimyasal işlemlerle protein yapısından ayrılması sağlanır. Bunu gerçekleştirmek için güçlü bir enzim olarak proteaz enzimini kullandım. Burada kimyasal reaksiyon olduğu için biyolojik katalizör kullanılmıştır"(E7)

Yukardaki Delil yapısına bakıldığında, araştırmacılar puanlama cetveline göre (E7)'nin delilini 5. düzey argüman olarak değerlendirmişlerdir. Çünkü DNA izalosyonu etkinliğinde amaç hücre duvarının parçalanması ve yapısal olarak destekleyen bileşenlerin ayrılması için gerekli olan işlem basamaklarının doğru bir şekilde ifade edilmesini sağlayan delillerin ortaya koyulmasıdır.

Tablo 3 .

Argümantasyon temelli hazırlanan deney raporlarındaki soru-iddia ve iddia-delil ilişkisinin gelişimi analiz sonuçları

\begin{tabular}{cccccc}
\hline \multirow{2}{*}{$\begin{array}{c}\text { Uygulama } \\
\text { No }\end{array}$} & $\mathrm{N}$ & \multicolumn{2}{c}{ Soru-İddia İlişkisi } & \multicolumn{2}{c}{ İddia- Delil İlişkisi } \\
\cline { 3 - 6 } & & $\mathrm{X}$ & $\mathrm{S} . \mathrm{S}$ & $\mathrm{X}$ & $\mathrm{S} . \mathrm{S}$ \\
\hline 1 & 46 & 1,32 &, 47 & 1,17 &, 38 \\
2 & 46 & 1,71 &, 45 & 1,76 &, 43 \\
3 & 46 & 2,41 &, 49 & 2,19 &, 41 \\
4 & 46 & 2,91 &, 41 & 2,80 &, 40 \\
5 & 46 & 3,32 &, 47 & 3,21 &, 42 \\
\hline
\end{tabular}

Tablo 3'de fen bilgisi öğretmen adaylarının ATBÖ yaklaşımına dayalı yazdıkları deney raporlarında üretmiş oldukları argumantasyon bileşenlerinden Soru-İddia ve İddia-Delil ilişkisi gelişimleri verilmiştir. Buna göre öğretmen adaylarının uygulamalarda üretmiş oldukları Soru-İddia argümanları ilişkisinden sırasıyla, "Farklı Hücre Yapılart" $\mathrm{X}=1,32$, "Organik Madde Tayini” $\mathrm{X}=1,71$, "Hücre Bölünmeleri” $\mathrm{X}=2,41$, "Kan Hücreleri” $\mathrm{X}=2,91$ ve "DNA İzolasyonu” $\mathrm{X}=3,32$ ortalama puan aldıkları tespit edilmiştir. İddia-Delil argümanlarının ilişkisi bağlamında ise, "Farklı Hücre Yaplları" $\mathrm{X}=1,17$, "Organik Madde Tayini” $\mathrm{X}=1,76$, "Hücre Bölünmeleri" $\mathrm{X}=2,19$, "Kan Hücreleri” $\mathrm{X}=2,80$ ve "DNA İzolasyonu” $\mathrm{X}=3,21$ ortalama puan aldıkları görülmüştür. Bu bulgulara dayalı olarak fen bilgisi öğretmen adaylarının deney raporlarında üretmiş oldukları argümanlardan Soruİddia ve İddia-Delil ilişkisi boyutları bağlamında beş haftalık sürede önemli bir gelişim gösterdikleri belirlenmiştir. 
Tablo 4.

Argümantasyon temelli hazırlanan deney raporlarındaki çoklu temsil ve yansıma boyutlarındaki gelişime ilişskin analiz sonuçları

\begin{tabular}{cccccc}
\hline \multirow{2}{*}{$\begin{array}{c}\text { Uygulama } \\
\text { No }\end{array}$} & $\mathrm{N}$ & \multicolumn{2}{c}{ Çoklu Temsil } & \multicolumn{2}{c}{ Yansıma } \\
\cline { 2 - 5 } & & $\mathrm{X}$ & $\mathrm{S} . \mathrm{S}$ & $\mathrm{X}$ & $\mathrm{S} . \mathrm{S}$ \\
\hline 1 & 46 & 1,08 &, 28 & 1,21 &, 41 \\
2 & 46 & 1,54 &, 50 & 1,89 &, 31 \\
3 & 46 & 2,19 &, 45 & 2,36 &, 48 \\
4 & 46 & 2,67 &, 47 & 3,04 &, 46 \\
5 & 46 & 2,97 &, 39 & 3,19 &, 40 \\
\hline
\end{tabular}

Tablo 4'de fen bilgisi öğretmen adaylarının АTBÖ yaklaşımına dayalı yazdıkları deney raporlarında üretmiş oldukları bileşenlerinden Çoklu Temsil ve Yansımalar argüman yapılarına göre beş haftalık gelişim bulguları verilmiştir. Buna göre öğretmen adaylarının Çoklu Temsil argümanı gelişiminde sırasıyla "Farklı Hücre Yapıları" X=1,08, "Organik Madde Tayini” X=1,54, "Hücre Bölünmeleri” X=2,19, "Kan Hücreleri” X=2,67 ve "DNA İzolasyonu" $\mathrm{X}=2,97$ ortalama puanlara ulaştıkları görülmektedir. Yansımalar argümanı gelişimine bakıldığında ise "Farklı Hücre Yapıları" $\mathrm{X}=1,21$, "Organik Madde Tayini" $\mathrm{X}=1,89$, "Hücre Bölünmeleri" $\mathrm{X}=2,36$, "Kan Hücreleri $\mathrm{X}=3,04$ ve "DNA İzolasyonu” $\mathrm{X}=3,19$ ortalama puanlara ulaştıkları tespit edilmiştir. Bu bulgulara dayalı olarak öğretmen adaylarının üretmiş oldukları Çoklu Temsil ve Yansımalar boyutlarında beş haftalık uygulama süresince önemli bir gelişim kaydettiği görülmüştür.

Tablo 5 .

Argümantasyon temelli hazırlanan deney raporlarındaki bütüncül düşünme boyutu gelişsimine ilişkin analiz sonuçları

\begin{tabular}{cccccc}
\hline \multirow{2}{*}{$\begin{array}{c}\text { Uygulama } \\
\text { No }\end{array}$} & $\mathrm{N}$ & \multicolumn{4}{c}{ Bütüncül Düşünme } \\
\cline { 3 - 6 } & & Min & Max & $\mathrm{X}$ & S.S \\
\hline 1 & 46 & 2,00 & 4,00 & 2,21 &, 62 \\
2 & 46 & 2,00 & 6,00 & 3,82 &, 71 \\
3 & 46 & 4,00 & 6,00 & 5,34 &, 95 \\
4 & 46 & 4,00 & 8,00 & 6,04 &, 66 \\
5 & 46 & 6,00 & 8,00 & 6,21 &, 63 \\
\hline
\end{tabular}

Tablo 5'te fen bilgisi öğretmen adaylarının ATBÖ yaklaşımına dayalı yazdıkları deney raporlarında üretmiş oldukları bileşenlerinden "Bütüncül Düşünme" argüman yapısına ilişkin beş haftalık gelişim bulguları verilmiștir. Buna göre öğretmen adaylarının Bütüncül Düşünme argümanı gelişiminde sırasıyla, "Farklı Hücre Yapıları" $\mathrm{X}=2,21$, "Organik Madde Tayini" $\mathrm{X}=3,82$, "Hücre Bölünmeleri" $\mathrm{X}=5,34$, "Kan Hücreleri" $\mathrm{X}=6,04$ ve "DNA İzolasyonu" X= 6,21 ortalama puanlar aldıkları tespit edilmiştir. Bu bulgulara dayalı olarak fen bilgisi öğretmen adaylarının üretmiş oldukları argümanların, bütüncül düşünme yapısına göre değerlendirildiğinde beş haftalık süreçte önemli bir gelişim gösterdiği belirlenmiştir.

\section{TARTIŞMA ve SONUÇ}

$\mathrm{Bu}$ araştırma, fen bilimleri eğitiminde önemli bir yer tutan laboratuvar uygulamalarında geleneksel deney raporu yazımı yerine, öğrenme üzerinde daha etkili olduğu araştırmalarla desteklenen ATBÖ yaklaşımına dayalı rapor yazımının, fen bilgisi öğretmen adaylarının sürece dayalı argüman yapılarının gelişimindeki etkisini incelemeyi amaçlamışıır. Araştırma beş haftalık Genel Biyoloji Laboratuvarı-I dersinde Farklı Hücre Yapıları, Kan Hücreleri, Organik Madde Tayini, Hücre Bölünmeleri ve DNA İzolasyonu konularıyla ilgili argümantasyon bileșenlerine dayalı hazırlanan deney raporlarıyla toplanmıștır. Bu araştırmada ATBÖ yaklaşımı öğrenci şablonu bileșenlerinden soru sorma, iddia ortaya koyma, iddialarını delillerle destekleme ve sürece dayalı düşüncelerindeki değişimleri yazıyla raporlaştırırma çalışmaları temel alınmıştır. $\mathrm{Bu}$ araştırma özünde deney raporlarındaki argümanların niteliğiyle ilgili sürece dayalı gelişimin incelenmesine dayanmaktadır. Fen eğitiminde argümantasyon bileșenlerinin gelişimi üzerine yapılan çalışmalar güçlü ve zayıf argümanların değerlendirilmesi (Hahn ve Oaksford, 2006; Eemeren ve Houtlosser., 2009) ve öğrencilerin düşüncelerini anlamanın bir yolu olarak argümantasyon çalışmaları üzerine yoğunlaşan bilişsel öğrenme araştırmalarını içermektedir (Hornikx ve Hahn, 2012). Fen eğitiminde öğrenci başarısını yukarıya taşıma çabaları içerisinde bugün belki de en dikkat çeken 
hususlardan birisi laboratuvar uygulamalarının nasıl olması gerektiği konusudur. Laboratuvar derslerinde öğrenci düşüncelerini yansıtmanın bir yolu olarak kullanılan raporlaştırma süreci buradaki oluşumların önemli bir boyutunu temsil etmektedir. Son yıllarda geleneksel laboratuvar uygulamaları perspektifinin dışında öğrencilerin bilimsel bilgiyi yapılandırmalarında daha ilgi çekici öğrenme yaklaşımlarının kullanıldığı görülmektedir (Kim ve Song, 2006; Peker ve Wallace, 2011). Özellikle uluslararası fen eğitimi litaratürü incelendiğinde laboratuvar öğrenmeleri üzerine argümantasyon ve sorgulamaya dayalı uygulama süreçlerinin bilimsel bilgiyi yapılandırmada geleneksel laboratuvar uygulamalarına kıyasla daha fazla katkı sağladığını ortaya koymaktadır (Hohenshell ve Hand, 2006; Katchevich ve diğ., 2011).

$\mathrm{Bu}$ araştırmada fen bilgisi öğretmen adaylarının süreç boyunca öğrenmelerine yön veren soruların niteliği her deney uygulamasında önemli bir gelişim göstermiştir (Tablo 1). Fen bilgisi öğretmen adaylarının ilk uygulama süreci olan Farklı Hücre Yapılarının Keşfi konusunda üretikleri soruların kalitesine bakıldığında ortalama 1,71 ortalama puandayken, son uygulama konusu olan DNA İzolasyonunda ise 3,21 ortalama puana ulaştıkları görülmüştür. Bu artış öğrencilerin sürece dayalı olarak daha niltelikli sorular ortaya koyduklarını göstermektedir. Fen eğitiminde öğrencilerin anlamlı bilgi yapıları elde etmelerinde kendi öğrenme süreçlerini sorgulamaları oldukça önemlidir. Bu bağlamda öğretmen adaylarının öğrenme beklentisini karşılayacak düşünceleri sorular eşliğinde ortaya koyarak sürece yön vermesi önemli bir aşamadır (Hand ve diğ., 2007). Uygulama süreci boyunca üretilen sorulara bakıldığında, öğretmen adaylarının ilk uygulamalarında sorgulamaya dayalı bir sürece yön vermede daha düşük nitelikte olan kapalı uçlu sorular ortaya koydukları görülmüştür. Bunun yanında öğrencilerin son uygulamalara doğru ortaya koydukları soruların, öğrenme sürecinde sorgulama ve eleştirel düşünme gibi üst düzey öğrenmeye yön verecek nitelikte etkili sorular olduğu görülmüștür. Laboratuvar uygulamaları boyunca bilimsel tartışmaya yön veren bu sorulardaki nitelik arttıkça yazılan raporlardaki diğer bileşenlerin gelişimi üzerinde de niteliksel olarak önemli bir gelişim olduğu belirlenmiştir. Argümantasyona dayalı uygulama süreçlerinde nitelikli soru oluşturabilmeye ilişkin yapılan araştırmalar, soru sorma yeteneğindeki gelişimin geleneksel öğrenme uygulamalarında düşük başarıda kalan öğrenciler için daha fazla sorumluluk alma konusunda güdüleyici olduğu ve önemli bir oryantasyon sürecine işaret ettiğini göstermektedir (Akkus ve diğ., 2007; Nam ve diğ., 2011). Yapılan araştırmalar, öğrencilerin ve öğretmenlerin öğrenme ortamında sordukları soruların sayısının öğrenme başarısı üzerinde önemli bir etki yapmadığı bunun yanında sorunun niteliğinin öğrenme başarısı üzerinde önemli bir etken olduğunu ortaya koymuştur (Günel ve diğ., 2012). Öğrenci düşüncelerine kılavuzluk edecek uygunlukta soru sorma yeteneği hem öğrenenin kendisi hemde diğerlerinin fikirleri üzerinde yansıtma yapmaları için çok önemlidir (Kuhn, 2009; Kuhn, 2010; Passmore ve Svoboda, 2012). Bunun yanında argümantasyon süreci ile soru sorma arasındaki ilişkinin niteliği kavramsal bilgiyi yapılandırma, derin ve eleştirel düşünceyi ilerletme potansiyeline sahiptir (Chin ve Osborne, 2010). Uygulama sürecinde fen bilimleri öğretmen adayları tarafindan argümantasyona dayalı yazılan deney raporlarındaki diğer bir argüman olan iddiaların niteliği süreç devam ettikçe önemli bir gelişim göstermiştir. İlk uygulamada öğretmen adaylarının iddialara ilişkin ortalama puanları 1,30 iken, son uygulamada 3,34 ortalama puana ulaştıkları görülmektedir. Cavagnetto ve diğ. (2010) araştırmalarında, argümantasyon bileşenlerden iddianın kalitesini sürece ilişkin beklentinin ve oluşturulacak sorgulamaya dayalı öğrenmenin bütünlüğü açısından önemli bir pedagojik aşama olarak değerlendirmişlerdir. Bu bakımdan araştırmada ortaya çıkan iddiaların kalitesi öğrenme sürecini yapılandırmada üst düzey düşünme becerileri geliştirilmesi açısından öğrencilere önemli pedagojik destek sağlamaktadır. Bilimsel tartışmaya ilişkin üretilen argümanların yapısındaki niteliksel değişim, öğrencilerin sürece ilişkin öğrenmelerinde daha fazla kavramsal anlayış sağlamasına yol açmaktadır (Posner ve diğ, 1982). Bu bakımdan iyi yapılandırılmış bir iddia, süreç boyunca üretilen bilgi yapılarının bütünlüğü ve daha anlaşılır kavramsal öğrenme süreçlerinin oluşturulması bakımından kıymetli bir oluşuma işaret etmektedir.

Araştırmanın diğer bir sonucu, ATBÖ yaklaşımına dayalı olarak fen bilgisi öğretmen adaylarının iddialarını kabul ettirebilmelerinin bir ölçüsü olarak ortaya koydukları delillere ilişkin gelişimleridir. Bu araştırmada fen bilgisi öğretmen adaylarının sürece dayalı olarak, hem soru hem de iddia kalitelerindeki gelişim ortaya konan delillerin niteliğini de geliştirmiş̧tir. Argümantasyona dayalı öğrenme süreçlerinde delillerin kalitesi arttıkça, elde edilmek istenenen sonuçların metabilişsel düzeyde öğrenenin kendi zihninde kabulünde önemli bir etken olduğu söylenebilir. Bilimsel bir tartışmanın gücünü, öğrenciler tarafindan toplanan verilerin yorumlanmasına dayalı olarak üretilen delillerin sunulması teşkil eder. Argümantasyona dayalı fen öğretimi araştırmaları öğrenenlerin iddialarını güçlendirmek için güçlü delil desteğinin sağlanması gerektiğine işaret etmektedir (Choi, 2008). Jimenez-Aleixandre ve diğ., (2000), delillerin öğrencilerin üst düzey düşünme becerileri kazanmalarında onlara açıklık kazandırdığına işaret etmektedir. Feni öğrenmede delil bileşeni, bilimsel düşüncenin anahtar boyutu olarak tanımlanır ve öğrencinin bilgiyi doğrulamasının temsili olarak ifade edilmektedir (Grandy, 1997; Prain \& Hand 1999). Yine başka bir araştırmada, Erduran (2006) delillerdeki niteliksel gelişmenin öğrencilerin, bilim insanlarının düşünme moduna sahip olmaları yönünde bir algı oluşturmalarını sağladığına dikkat çekmişlerdir. Maloney ve Simon (2006) araştırmalarında, argümantasyon uygulamalarında delillerin niteliğinin öğrencilerin karar alma becerilerine önemli bir etki yaptığını ifade etmişlerdir. Yine birçok araştırma delillerin niteliğindeki artışın, öğrencilerin bilimi anlayabilme ve iletişime geçebilme yollarına iliş̧in yeteneklerinin gelişimini büyük oranda desteklediğini göstermektedir (Cronje ve diğ., 2011; Andrews ve diğ., 2009) 
Araştırmada fen bilgisi öğretmen adaylarının beş haftalık uygulama boyunca deney raporlarındaki soru ve iddialar arasındaki ilişkinin niteliğine ait bulgularında önemli bir gelişim kaydettiklerini göstermektedir. Deney konularıyla ilgili soruların kalitesindeki artış ve bu sorulardan yola çıkarak öğrenci düşüncelerinin bir yansıması olarak geçmişten getirdikleri bilgi yapılarını sorgulama yolu olarak bunları iddialarıyla ilişkilendirmeleri bilimsel olarak düşünceyi formüle edebilme yolunda önemli bir adımdır (Cronje ve diğ., 2011). Choi (2008) araştırmasında soru-iddialar arasında kurulan anlamlı ilişkinin, sorgulanmak istenen fikirler için öğrencide bilişsel bütünlük sağlayacağını belirtmektedir. Bu bağlamda ortaya çıkan soru-iddia ikilisi arasındaki ilişkinin kalitesi argümantasyon sürecinin bütünlüğü açısından önemli bir aşama olduğu söylenebilir. Araştırmada fen bilgisi öğretmen adaylarının iddia-delil arasındaki ilişkinin durumunu ortaya koyduğu bulgular argümantasyona dayalı deney raporu yazma uygulaması süreci boyunca bu ikilinin arasında kurulan bağın niteliğinde önemli bir gelişme olduğunu göstermektedir. Bu sonuca dayalı olarak öğrencilerin ortaya koymuş oldukları iddiaların, her uygulama süreci boyunca daha sağlam delillerle ilişkilendirdikleri görülmüş̧ür. Öğrencilerin ilk uygulama sürecinde elde ettikleri delillerin iddialarıyla çok uyum içinde olmadığı, ilerleyen uygulama süreçleri boyunca daha güçlü ve etkili deliller ortaya koyarak iddialarını destekledikleri görülmüştür. Bu sonuç, fen eğitimi araştırmalarda iddia ve buna uygun delil ilişkisinin önemini ortaya koyan birçok çalışmayla desteklenmiştir. Bu çalışmalarda, iddia ve delil argümanları arasındaki kurulan ilişkinin niteliğindeki gelişim öğrencilerin kavramsal öğrenmelerinde ve bilimsel bilgiyi etkili bir şekilde yapılandırmalarında önemli olduğunu vurgulamaktadır (Choi, 2008; Hand ve diğ., 2007; Hand ve Choi, 2010). Araştırmanın bu sonucuna dayalı olarak güçlü bir argümantasyon uygulamasında iddia ve delil arasındaki ilişkinin niteliği anlamlı öğrenme süreçleri açısından önemli katkılar sunduğu söylenebilir. Yine iddia ve delil arasındaki ilişkinin önemi üzerine ilgili alan yazındaki diğer bir araştırmada, Sandoval ve Millwood (2005) bilimsel tartı̧̧manın gelişmesinde bu iki argüman arasında kurulan ilişkinin niteliğinin, amaçlanılan kavramsal anlayışın gelişmesi için kritik bir öneme sahip olduğunu belirtmişlerdir. Ayrıca argümantasyona dayalı öğreme süreçlerinde, öğrencilerin ortaya koydukları iddia ve delilleri nasıl ilişkilendirdiklerini açıklayabilmeleri bilimsel düşünme yeteneklerini kullanmalarını gerektirmektedir (Llewellyn ve Rajesh, 2007). Bu bakımdan bu iki bileşen arasında kurulan ilişkinin niteliği öğrencinin bilimsel düşüncesine yön vermede önemli bir köprü görevi yapmaktadır.

Araştırmada, fen bilgisi öğretmen adaylarının düşüncelerini değerlendirmek için görsel destek sağlayan çoklu temsil yapıları (grafik, diyagram vb.) argümantasyon uygulamaları boyunca çeşitlenmiştir. İlk uygulamada öğrenci raporlarında çoğunlukla düz metin yapıları kullanıldığı, uygulama süreçleri devam ettikçe bu metinlerin yerine daha çok grafikler, diyagramlar, resimler ve tabloların yerleştiği görülmüsstür. Öğrenci düşüncesinin görselleştirilmesini sağlayan bu yapılar, argümantasyon çalışmalarında düşünce ve iletişimin temsil kaynakları olarak önemli katkılar sağlamaktadırlar (Baker, 2003; Chin ve Osborne, 2010). Araştırmada yine diğer bir boyut olan fen bilgisi öğretmen adaylarının fikirlerindeki değişimin ifadesi olarak yansımalar bileşenine ait bulgular, ilk uygulama sonucunda fikirlerinin değişim nedeniyle ilgili yaptıkları açıklamalarda çok zayıf kaldıkları ve sahip oldukları bilgi yapılarıyla ilişki kurmada da yine çok yetersiz kaldıklarını göstermiştir. Bunun yanında süreç ilerledikçe son uygulamalara doğru fikirlerindeki değişimin nedenlerine uygun açıklamalar yaptıkları görülmüştür. Ayrıca bu fikirleri hem zihinlerinde var olan bilgi yapılarıyla ilişkilendirdikleri hemde gerçek yaşamdan örneklerle açıkladıkları görülmüş̧ür. Araştırmadan elde edilen bu sonuç, Yore ve diğ., (2003) çalışmalarını destekler niteliktedir. Araştırmacılar bu çalışmalarında, bilimsel öğrenme sürecine ilişkin olarak öğrencilerin oluş̧urdukları argümantasyon bileşenlerinin kalitesini, zihinsel muhasabelerinin birer aynası olarak ifade etmişlerdir. Argümantasyona dayalı öğrenme süreciyle öğrenciler düşüncelerindeki değişimi yansıtarak, zihinlerindeki bilgi yapılarını yeniden organize etme yollarını keşfetme ve öğrenmeye ilişkin farkındalığı iyileştirme firsatı yakalamaktadırlar (Hohenshell ve Hand, 2006). Bu bağlamda düşünüldüğünde, deney uygulamaları ve argümantasyon arasında kurulan bağ öğrencilerin sahip oldukları düşünceleri yansıtmaları açısından önemli bir firsat sunmaktadır (Kim ve Song, 2006). Araştırmanın son bulgusu olan bütüncül değerlendirme boyutu, ilk uygulamadan son uygulamaya önemli bir gelişim gösterdiği tespit edilmiştir. Araştırma fen bilgisi öğretmen adaylarının ilk deney konusunda bilimsel tartı̧̧a süreci argümanları bakımından, daha zayıf ve test edilmez sorular, geçersiz iddialar, iddialarını destekleyecek düşük kalitede deliller ve bunlar arasında zayıf bir ilişki kurduklarını göstermektedir. Bu durumun uygulama süreçleri devam ettikçe değiştiği daha zengin bir bilimsel tartışma oluşturdukları, daha nitelikli sorular, iddialar, güvenilir deliller sundukları ve bu bileşenler arasında mantıklı ilişkilendirmelerin yapıldığı görülmüștür. Bilimsel tartışma sürecinin farklı bileşenleri arasındaki uyumun kalitesi, öğrencilerin bilimsel bilgiyi inşa etmeleri ve üst düzey düşünme becerileri geliştirmelerinde çok önemlidir (Martin ve Hand, 2009).

Araştırmanın sonuçları ortaya koymaktadır ki, fen bilgisi öğretmen adaylarının lisans dönemi boyunca anlamlı öğrenmelerini desteklemek ve kavramsal anlayışlarını geliştirmek için argümantasyona dayalı bilim öğrenme yaklaşımını temel alan uygulamaları laboratuvar derslerinde kullanmaları adayların yetişme sürecine çok önemli katkılar sunmaktadır (Hohenshell ve Hand, 2006; Yore ve diğ., 2003; Cronje ve diğ., 2011). Laboratuvar derslerinde bilimsel bilginin anlamlı bir şekilde sorgulanarak yapılandırılmasında, АTBÖ yaklaşımı yeni ve ilgi çekici bir perspektiftir. Bu bağlamda araştırmamız ülkemizde laboratuvar uygulamalarında çok fazla yer verilmeyen argümantasyona dayalı bilim öğrenme yaklaşımının kullanıldığı bir hizmet öncesi eğitim çalışmasıdır. 
$\mathrm{Bu}$ araştırma göstermektedir ki hem öğrenciler hemde eğitimciler için bilimsel bilginin yapılandırılmasında klasik metotların yerine daha çok bilimsel sorgulamanın ve tartışmanın yapıldığı oluşumların öğrenme süreçlerine entegre edilmeleri son derece önemlidir. Ayrıca yine bu araştırmayı destekler nitelikte, öğrenciler için bilimsel kavramların sözlü ve yazılı olarak bir bütünlük içinde sunulduğu argümantasyon uygulamaları öğrenme başarısında önemli farklılıklar yarattı̆̆ı birçok çalışmayla desteklenmektedir (Osborne, 2007; Kaya ve Kılıç, 2008; Hewson ve Ogunniyi, 2011). Bu araştırmanın sonuçları ışı̆̆ında genel bir öneri olarak söyleyebiliriz ki; anlamlı öğrenme süreçlerinin yapılandııılmasında fark yaratan argümantasyon uygulamaları, sadece sınıf ortamında fen konuları öğrenilirken değil, fen eğitiminin ayrılmaz parçası olan laboratuvar uygulamalarında da kullanılması öğrencilerin hem kavramsal anlayışlarını hem de bilimsel açıklamalarını dil, düşünce ve yazıya dayalı bir süreç içerisinde bütünleşmelerini sağlamada etkin bir yoldur (Cronje ve diğ., 2011). Bu bağlamda araştırmamız laboratuvar uygulamalarında argümantasyona dayalı bilimsel rapor yazımı konusunda eğitimcilere örnek bir çalışma olması bakımından önemlidir. Bunun yanında laboratuvar dersleri kapsamında ATBÖ yaklaşımına dayalı olarak öğrenci öğrenmelerine katkı sağlayacak farklı örneklem ve fen konularını içeren daha fazla sayıda deney raporu yazım çalışmalarının yapılmasına ihtiyaç vardır.

\section{KAYNAKÇA}

Akçay, H., Hand, B., \& Norton-Meier, L. (2010). "Creative writing and promoting understanding in science: Alternative ways to interest students in writing about science", School Science Review, Vol.92, pp.49-53.

Akkus, R., Günel, M., \& Hand, B. (2007). Comparing an Inquiry-Based Approach Known as the Science Writing Heuristic to Tradional Science Teaching Pratices: Are there differences? International Journal of Science Education, 29:14, 1745-1765.

Andrews, R., Torgerson, C., Low, G. \& McGuinn, N. (2009). Teaching argument writing to 7- to 14-year-olds: an international review of the evidence of successful practice, Cambridge Journal of Education, 39:3, 291310.

Armstrong, N. A., Wallace, C. S., \& Chang, S. M. (2008). Learning from Writing in College Biology, Res Sci Educ, 38:483-499.

Aslan, S., \& Tekin, N. (2015). Laboratuar Uygulamalarını Argümantasyon Tabanlı Bilim Öğrenme Rapor Formatına Göre Raporlaştırmanın Kavramsal Anlamaya ve Modsal Betimleme Kullanımına Etkisi. Erzincan Üniversitesi Eğitim Fakültesi Dergisi Cilt-Sayı: 17-1, 73-97.

Baker, W. P., Barstack, R., Clark, D., Hull, E., Goodman, B., Kook, J., Kraft, K., Ramakrishna, P., Roberts, E., Shaw, j., Weaver, D., \& Lang, M. (2008). Writing-to-Learn in the Inquiry-Science Classroom: Effective Strategies from Middle School Science and Writing Teachers, The Clearing House: A Journal of Educational Strategies, 81:3, 105-108.

Baker, M. (2003). Computer mediated argumentative interactions for the co-elaboration of scientific notions. In J. Andriessen, M. Baker, \& D. Suthers (Eds.), Arguing to learn: Confronting cognitions in computersupported collaborative learning environments (pp. 47-78). Dordrecht, The Netherlands: Kluwer.

Berland, L. K., \& McNeill, K. L. (2009). Using A Learning Progression To Inform Scientific Argumentation In Talk And Writing, Paper presented at the Learning Progressions in Science (LeaPS) Conference, June 2009, Iowa City, IA.

Böttcher, F., \& Meisert, A. (2011). Argumentation in Science Education: A Model-based Framework, Sci \& Educ, 20:103-140.

Bricker, L., \& Bell, P. (2009). Conceptualizations of argumentation from science studies and the learning sciences and their implications for the practices of science education. Science Education, 92, 473-498.

Cavagnetto, A., Hand, B. M., \& Norton-Meier, L. (2010). The Nature of Elementary Student Science Discourse in the Context of the Science Writing Heuristic Approach. International Journal of Science Education, $32: 4,427-449$.

Chin, C., \& Osborne, J. (2010). Supporting Argumentation Through Students' Questions: Case Studies in Science Classrooms, Journal of the Learning Sciences, 19:2, 230-284.

Chen, Y. C., Hand, B., \& Park, S. (2016). Examining Elementary Students' Development of Oral and Written Argumentation Practices Through Argument-Based Inquiry. Sci \& Educ, 25:277-320.

Choi, A. (2008). A Study of Student Written Argument Using The Science Writing Heuristic Approach in InquiryBased Freshman General Chemistry Laboratory Classes, May 2008, UMI Microform 3323405 Copyright 2008 by ProQuest LLC.

Choi, A., Notebaert, A., Diaz, J., \& Hand, B. (2010) Examining Arguments Generated by Year 5, 7, and 10 Students in Science Classrooms, Res Sci Educ (2010) 40:149-169.

Choi, A., Hand, B., \& Greenbowe, T. (2013). Students' Written Arguments in General Chemistry Laboratory Investigations. Res Sci Educ, 43:1763-1783. 
Cronje, R., Murray, K., Rohlinger, S., \& Wellnitz, T. (2011). Using the Science Writing Heuristic to Improve Undergraduate Writing in Biology, International Journal of Science Education, 1-14.

D'Avanzo, C. (2003). Application of research on learning to college teaching: Ecological examples. Bioscience, 53, 1121-1128.

Dawson, V. M., \& Venville, G. (2010). Teaching Strategies for Developing Students'Argumentation Skills About Socioscientific Issues in High School Genetics, Res Sci Educ, 40:133-148.

Durna, T. (2010). Örnekleme. (Ed. K. Böke). Sosyal Bilimlerde Araştırma Yöntemleri, (s.186). İstanbıl: Alfa Yayıncilık, 2. Basım, ISBN: 978-605-106-067-5.

Duschl, R. A., Schweingruber, H. A., \& Shouse, A. E. (Eds.). (2007). Taking science to school: Learning and teaching science in grades $K-8$. Washington, DC: National Academies Press.

Eemeren, F. H. van., \& Houtlosser, P. (2009). Seizingthe occasion: Parametersfor analysingways of strategic manocuvring. In F. H. van Eemeren \& B. Garssen (Eds.), Pondering on problems of argumentation. Twenty essays on theoretical issues (pp. 3-14). Amsterdam: Springer.

Erduran, S. (2006). Promoting ideas, evidence and argument in initial science teacher training, School Science Review, June, 87(321), 45-50.

Erduran, S., Ardac, D., \& Yakmaci-Guzel, B. (2006). Learning to Teach Argumentation: Case Studies of PreService Secondary Science Teachers, Eurasia Journal of Mathematics, Science and Technology Education, Volume 2, Number 2.

Erduran, S., \& Jime'nez-Aleixandre, M. P. (2011). Argumentation in Science Education: Perspectives from Classroom-Based Research, Sci \& Educ, 20:585-588.

Erduran, S., \& Jime'nez-Aleixandre, M. P. (Eds.). (2007). Argumentation in Science Education: Recent developments and future directions. New York: Springer.

Furtak, E. M., \& Alonzo, A. C. (2010). The Role of Content in Inquiry-Based Elementary Science Lessons: An Analysis of Teacher Beliefs and Enactment. Res Sci Educ, 40:425-449, DOI 10.1007/s11165-009-9128-y

Goldston, M. J., Bland Day, J., Sundberg, C \& Dantzler, J. (2010). Psychometric Analysis Of A 5E Learning Cycle Lesson Plan Assessment Instrument, International Journal of Science and Mathematics Education, 8: 633648.

Grandy, R. E. (1997). 'Constructivisms and Objectivity: Disentangling Metaphysics from Pedagogy', Science \& Education, 6(1-2), 43-53.

Günel, M., Atila, M. E., \& Büyükkasap, E. (2009). The Impact of Using Multi Modal Representations within Writing to Learn Activities on Learning Electricity Unit at 6th Grade, Elementary Education Online, 8(1), 183-199, http://ilkogretim-online.org.tr.

Günel, M., Kıngır, S., \& Geban, Ö. (2012). Argümantasyon Tabanlı Bilim Öğrenme(ATBÖ) Yaklaşımının Kullanıldığı Sınıflarda Argumantasyon ve Soru Yapılarının İncelenmesi. Eğitim ve Bilim, Cilt 37,Sayı 164, syf:316-330.

Haefner, L. A., \& Zembal-Saul, C. (2004). Learning by doing? Prospective elementary teachers' developing understandings of scientific inquiry and science teaching and learning. International Journal of Science Education 26(13), 1653 - 1674.

Hahn, U., \& Oaksford, M. (2006). The Rationality of Informal Argumentation: A Bayesian Approach to Reasoning Fallacies. Psychological Review, Vol. 114, No. 3, $704-732$.

Hakyolu, H., \& Ogan-Bekiroglu, F. (2011). Assessment of Students' Science Knowledge Levels and Their Involvement with Argumentation, International Journal for Cross-Disciplinary Subjects in Education (IJCDSE), Volume 2, Issue 1, 264-270.

Hand, B., \& Choi, A. (2010). Examining the impact of student use of multiple modal representations in constructing arguments in organic chemistry laboratory classes. Research in Science Education, 40(1), 2944.

Hand, B., Hohenshell, L., \& Prain, V. (2007). Examining the effect of multiple writing tasks on Year 10 biology students' understandings of cell and molecular biology concepts. Instructional Science (2007) 35:343-373.

Hand, B., \& Prain, V. (2001) Teachers Implementing Writing-To-Learn Strategies in Junior Secondary Science: A Case Study

Hand, B., Hohenshell, L., \& Prain, V. (2007). Examining the effect of multiple writing tasks on Year 10 biology students' understandings of cell and molecular biology concepts. Instructional Science (2007) 35:343-373.

Hand, B., Yang, O. E., \& Bruxvoort, C. (2007). Using Writing-To-Learn Science Strategies to Improve Year 11 Students' Understandings of Sto1chiometry, International Journal of Science and Mathematics Education (2007) 5: 125-143.

Hand, B., Gunel, M., \& Ulu, C. (2009). Sequencing Embedded Multimodal Representations in a Writing to Learn Approach to the Teaching of Electricity, Journal of Research in Science Teaching, Vol. 46, No. 3, pp. 225247. 
Hand, B., Wallance, C. W., \& Yang, E. M. (2004). Using a Science Writing Heuristic to enhance learning outcomes from laboratory activities in seventh-grade science: quantitive and qualitive aspects. International Journal of Science Education, Volume 26, Issue 2, 131-149.

Hornikx, J., \& Hahn, U. (2012). Reasoning and argumentation: Towards an integrated psychology of argumentation, Thınkıng \& Reasoning, 18 (3), 225-243.

Hapgood, S., \& Palincsa, A. S. (2006). Where Literacy and Science Intersect, Educational Leadership, Vol.64, Number:4, p:56-60.

Hewson, M. G., \& Ogunniyi, M. B. (2011). Argumentation-teaching as a method to introduce indigenous knowledge into science classrooms: opportunities and challenges, Cult Stud of Sci Educ (2011) 6:679-692.

Hofstein, A., Cohen, I., \& Lazarowitz, R. (1996). The learning environment of high school students in chemistry and biology laboratories. Research in Science and Technological Education, 14, 103-115.

Hohenshell, 1. M., \& Hand, B. (2006). Writing-to-learn Strategies in Secondary School Cell Biology: A mixed method study, International Journal of Science Education, 28:2-3, 261-289.

Jiménez-Aleixandre, M. P., Bugallo Rodríguez, A., \& Duschl, R. A. (2000). "Doing the lesson" or “doing science": Argument in high school genetics. Science Education, 84(6), 757-792.

Karamustafaoğlu, O. (2009). Fen ve Teknoloji Eğitiminde Temel Yönelimler, Cilt:17, No:1 Kastamonu Eğitim Dergisi, 87-102.

Katchevich, D., Hofstein, A., \& Mamlok-Naaman, R (2011). Argumentation in the Chemistry Laboratory: Inquiry and Confirmatory Experiments, Res Sci Educ, DOI 10.1007/s11165-011-9267-9, Springer Science+Business Media B.V.

Kaya, O. N., \& Kılıç, Z. (2008). Etkin Bir Fen Öğretimi İçin Tartışmacı Söylev, Ahi Evran Üniversitesi Kırşehir Eğitim Fakültesi Dergisi (KEFAD), Cilt 9, Sayı 3, (89-100).

Keys, K. W. (1999). Revitalizing Instruction in Scientific Genres: Connecting Knowledge Production with Writing to Learn in Science, John Wiley \& Sons, Inc. CCC 0036-8326/99/020115-16.

Keys, C. W., Hand, B., Prain, V., \& Collins, S. (1999). Using the science writing heuristic as a tool for learning from laboratory investigations in secondary science. Journal of Research in Science Teaching, 36(10), 1065-1084.

Kıngır, S., Geban, Ö., \& Günel, M. (2011). Öğrencilerin Kimya Derslerinde Argümandaysan Tabanlı Bilim Öğrenme Yaklaşımının Uygulanmasına İlişkin Görüşleri, Ahmet Keleşoğlu Eğitim Fakültesi Dergisi, say1:32,15-28.

Kim, H., \& Song, J. (2006). The Features of Peer Argumentation in Middle School Students' Scientific Inquiry, Research in Science Education, 36: 211-233.

Kieft, M., Rijlaarsdam, G., \& Bergh, H. V. (2006). Writing as a learning tool: Testing the role of students' writing strategies European Journal of Psychology of Education 2006, Vol. XXI, $n^{\circ} 1,17-34$.

Klein, P. D. (1999). Reopening Inquiry into Cognitive Processes in Writing-To-Learn, Educational Psychology Review, Vol. 11, No. 3, 203-268, Cognitive Processes in Learning Through Writing.

Klein, P. D. (2000). Elementary Students' Strategies for Writingto- Learn in Science, Cognition and Instruction, $18: 3,317-348$.

Klein, P. D. (2006). The challenges of scientific literacy: From the viewpoint of second generation cognitive science. International Journal of Science Education, 28, 143-178.

Koray, Ö., Köksal, M.S., Özdemir, M., \& İrfan Presley, A. (2007). The effect of creative and critical thinking based laboratory applications on academic achievement and science process skills, Elementary Education Online, 6(3), 377-389, http://ilkogretim-online.org.tr.

Kuhn, D. (2010). Teaching and Learning Science as Argument, Science Education, 810-824, Published online in Wiley Online Library (wileyonlinelibrary.com).

Kuhn, D. (2009). Do students need to be taught how to reason? Educational Research Review, 4(1), 1-6.

Levin, T., \& Wagner, T. (2006). In their own words: Understanding student conceptions of writing through their spontaneous metaphors in the science classroom, Instructional Science, 34: 227-278.

Llewellyn, D. \& Rajesh, H. (2007). Fostering Argumentation Skills DoingWhat Real Scientists Really Do, Science Scope, 22-28.

Maloney, J. \& Simon, S. (2006). Mapping Children's Discussions of Evidence in Science to Assess Collaboration and Argumentation, International Journal of Science Education, 28:15, 1817-1841.

Mateos, M., Martin, E., Villalon, R., \& Luna, M. (2008). Reading and writing to learn in secondary education: online processing activity and written products in summarizing and synthesizing tasks. Reading and Writing: An Interdisciplinary Journal, 21, 675-697.

Martin, A. M., \& Hand, B. (2009). Factors Affecting the Implementation of Argument in the Elementary Science Classroom: A Longitudinal Case Study, Res Sci Educ, 39:17-38.

Mason, L. (1998). Sharing cognition to construct scientific knowledge in school context: The role of oral and written discourse, Instructional Science 26: 359-389, 1998. 1998 Kluwer Academic Publishers. Printed in the Netherlands. 
Mason, L., \& Boscolo, P (2000). Writing and conceptual change. What changes?. Instructional Science, 28: 199226.

McDermott, M. A., \& Hand, B. (2012). The impact of embedding multiple modes of representation within writing tasks on high school students' chemistry understanding, Instr Sci, DOI 10.1007/s11251-012-9225-6, Springer Science+Business Media B.V.

Morgil, I., Güngör Seyhan, H., \& Seçken, N. (2009). Proje destekli kimya laboratuarı uygulamalarının bazı bilişsel ve duyuşsal alan bileşenlerine etkisi. Türk Fen Eğitimi Dergisi, 6(1), 89-107.

Nam, J., Choi, A., \& Hand, B. (2011). Implementation of the Science Writing Heuristic(SWH) Approach in 8th Grade Science Classrooms, International Journal of Science and Mathematics Education, 9: 1111-1133, National Science Council, Taiwan.

National Research Council (NRC). (2000). Inquiry and the national science education standards. Washington, D. C: National Academy Press.

Neuman, W. L. (2000). Social Research Methods: Qualitative and Quantitative Approaches, 4th ed. (Boston: Allyn and Bacon)

Norman, O., Ault Jr, C. R., Bentz, B., \& Meskimen, L. (2001). The black-white “achievement gap" as a perennial challenge of urban science education: A sociocultural and historical overview with implications for research and practice, Journal of Research in Science Teaching, Volume 38, Issue 10, pages 1101-1114.

Nückles, M., Hübner, S., Dümer, S., \& Renkl, A. (2010). Expertise reversal effects in writing-to-learn, Instr Sci, 38:237-258.

Ogunniyi, M. B., \& Hewson, M. G. (2008). Effect of an Argumentation-Based Course on Teachers' Disposition towards a Science-Indigenous Knowledge Curriculum, International Journal of Environmental \& Science Education, Vol. 3, No. 4, 159-177.

Osborne, J. (2007). Towards a more social pedagogy in science education: the role of argumentation, Revista Brasileira de Pesquisa em Educação em Ciências Vol. 7, No 1.

Osborne, J., Simon, S., \& Erduran, S. (2002). Enhancing the guality of argumantation in school science. Paper presented at the international conference Ontological, Epistemological, Linguistics and Pedagogical Considerations of Language and Svience Literacy: Empowering Research and Informing Instruction, Victoria, BC, Canada.

Osborne, J., Erduran, S., \& Simon, S. (2004). Enhancing the Quality of Argumentation in School Science, Journal of Research in Science Teaching, Vol. 41, NO. 10, pp. 994-1020.

Özmen, H. (2004). Fen Öğretiminde Öğrenme Teorileri ve Teknoloji Destekli Yapılandırmacı (Constructivist) Öğrenme, The Turkish Online Journal of Educational Technology - TOJET, Volume 3, Issue 1, pp. 100111.

Papadopoulos, P. M., Demetriadis, S. N., Stamelos, I. G., \& Tsoukalas, I. A. (2011) The value of writing-to-learn when using question prompts to support web-based learning in ill-structured domains. Education Tech Research Dev, 59:71-90

Passmore, C. M., \& Svoboda, J. (2012): Exploring Opportunities for Argumentation in Modelling Classrooms, International Journal of Science Education, 34:10,1535-1554.

Peker, D., \& Wallace, C. S. (2011). Characterizing High, 2011 School Students' Written Explanations in Biology Laboratories, Res Sci Educ, 4:169-191.

Poock, J. R., Burke, K. A., Greenbowe, T. J., \& Hand, B. M. (2007). Using the science writing heuristic in the general chemistry laboratory to improve students' academic performance. Journal of Chemical Education, 84(8),1371-1379.

Porter, M. K., \& Masingila, J. O .(2000). Examining The Effects of Writing on Conceptual and Procedural Knowledge in Calculus, Educational Studies in Mathematics 42: 165-177, 2000. (C) 2001 Kluwer Academic Publishers. Printed in the Netherlands.

Posner, G. J., Strike, K. A., Hewson, P. W., \& Gertzog, W. A. (1982). Accommodation of a scientific conception: Toward a theory of conceptual change. Science Education, 66(2), 211-227.

Prain, V. \& Hand, B.(1999). 'Students Perceptions of Writing for Learning in Secondary School Science', Science Education 83(2), 151-162.

Prain, V \& Waldrip, B. (2010). Representing Science Literacies: An Introduction, Res Sci Educ, 40:1-3.

Prain, V., Tytler, R., \& Peterson, S. (2009). Multiple Representation in Learning About Evaporation, International Journal of Science Education, 31:6, 787-808.

Rivard, L. P., \& Straw, S.W. (2000). The effect of talk and writing on learning science: An exploratory study. Science\&Education, 84, 566-593.

Rogers, M. A., Abell, S. K., Marra, R. M., Arbaugh, F., Hutchins, K. L.,\& Cole, J. S.(2010). Orientations to Science Teacher Professional Development: An Exploratory Study. J Sci Teacher Educ, 21:309-328.

Sandoval, W. A., \& Millwood, K. A. (2005). The Quality of Students' Use of Evidence in Written Scientific Explanations. Cognition and Instruction, Volume 23, Issue 1, pp. 23-55. 
Sampson, V. (2009). Science teachers and scientific argumentation: Trends in practice and beliefs. Paper presented at the Annual International Conference of the National Association of Research in Science Teaching (NARST). Garden Grove, CA

Sönmez, V., \& Alacapınar, F.G. (2014). Örneklendirilmiş Bilimsel Araştırma Yöntemleri (3.Baskı), Ankara: Anı Yayıncilik.

Schroeder, C. M., Scott, T. P., Tolson, H., Tse-Yang, H., \& Yi-Hsuan., L. (2007). A meta-analysis of national research: Effects of teaching strategies on student achievement in science in the United States Journal of Research in Science Teaching, Volume 44, Issue 10, pages 1436-1460.

Sharma, A., \& Anderson, C.W. (2009) Recontextualization of Science from Lab to School: Implications for Science Literacy, Sci \& Educ, 18:1253-1275.

Takao, A. Y., \& Kelly, G. J. (2003) Assessment of Evidence in University Students' Scientific Writing, Science \& Education, 12: 341-363.

Tippet, C. (2009). Argumentation: The Language of Scince, Journal of Elementary Science Education, Vol. 21, No.1, 17-25, Document and Publication Services, Western İllinois Univ.

Tomas, L., \& Ritchie, S. M. (2012). Positive Emotional Responses to Hybridised Writing about a Socio-Scientific Issue, Res Sci Educ, 42:25-49.

Tseng, C. H., Tuan, H. L., \& Chin, C. C. (2013). How to Help Teachers Develop Inquiry Teaching: Perspectives from Experienced Science Teachers, Res Sci Educ Res Sci Educ, 43:809-825.

Von Secker, C. E., \& Lissitz, R. W. (1999). Estimating the Impact of Instructional Practices on Student Achievement in Science, Journal of Research in Science Teaching, Volume 36, Issue 10, pages 1110-1126.

Walker, J. P. (2011). Argumentation in undergraduate Chemistry Laboratories, The Florida State University College of Education, Doctor of Philosophy, Spring Semester.

Wee, B., Shepardson, D., Fast, J.\&Harbor, J. (2007). Teaching and Learning About Inquiry: Insights and Challenges in Professional Development, Journal of Science Teacher Education, 18:63-89.

Yeşilyurt, S. (2006). Öğretmen adayları ve öğretim elemanları gözüyle genel biyoloji laboratuar uygulamalarının değerlendirilmesi. Kastamonu Eğitim Dergisi, 14 (2), 481-496.

Yore, L., Bisanz, G. Y., \& Hand, B. (2003). Examining the literacy component of science literacy: 25 years of language arts and science research, International Journal of Science Education, 25:6, 689-725.

Zembal-Saul, C. (2009). Learning to Teach Elementary School Science as Argument, Science Education, Volume 93, Issue 4, 688-719. 


\section{Ek:1 Argüman Yapılarının Niteliğini Değerlendirmek İçin Öğrenci Deney Raporu Puanlama Ölçütleri}

\begin{tabular}{|c|c|c|}
\hline Puan & Soruların kalitesi & İddiaların kalitesi \\
\hline 1 & $\begin{array}{ll}\text { - } & \text { Tek ve kapalı uçlu soru } \\
\text { - } & \text { Sorular test edilemez } \\
\text { - Önemsiz ve zayıf sorular } \\
\text { - } \quad \text { Sorular özü yakalayamaz ve düşük kalitededir }\end{array}$ & $\begin{array}{ll}\text { - } & \text { Tek iddia ve İddialar hiçbir veri ve gözleme } \\
& \text { dayanmaz } \\
\text { - } & \text { İddialar araştırmanın özünü yakalayamaz } \\
\text { - } & \text { İddia önemsizdir } \\
\text { - } & \text { İddia geçersizidir ve doğrulanamaz }\end{array}$ \\
\hline 2 & $\begin{array}{ll}- & \text { Bir kaç kapalı uçlu soru } \\
\text { - } & \text { Test etmek zor olabilir } \\
\text { - } & \text { Sorular araştırmanın özünü yakalayamaz } \\
\text { - } & \text { Sorular önemli ve yeterli olmayabilir } \\
\text { - } & \text { Sorular düşük kalitede olabilir } \\
\end{array}$ & $\begin{array}{ll}- & \text { Tek yâda çoklu iddia } \\
\text { - } & \text { İddialar deneysel veri ve gözlemlerden gelmiş } \\
& \text { gözükmez } \\
\text { - } & \text { İddialar araştımanın özünü yakalayamayabilir } \\
\text { - } & \text { İddialar önemsiz ve yetersiz olabilir } \\
\end{array}$ \\
\hline 3 & $\begin{array}{ll}\text { - } & \text { Kapalı uçlu birçok soru } \\
\text { - } & \text { Test edilebilir ve anlamlı sorulardır } \\
\text { - } & \text { Sorular araştırmanın özünü yakalayabilir } \\
\text { - } & \text { Sorular önemli ve yüksek kalitededir }\end{array}$ & $\begin{array}{ll}\text { - } & \text { Tek yâda çoklu iddia } \\
\text { - } & \text { İddialar deneysel veri ve gözlemlerden olabilir } \\
\text { - } & \text { İddialar araştırmanın özünü yakalayabilir } \\
\text { - } & \text { İddialar yeterli ve yüksek kalitede olabilir }\end{array}$ \\
\hline 4 & $\begin{array}{ll}- & \text { Enaz bir açık uçlu soruyu içeren çok soru } \\
\text { - } & \text { Test edilebilir sorulardır } \\
\text { - } & \text { Sorular araştırmanın özünü yakalar ve yüksek } \\
& \text { kalitededir } \\
\end{array}$ & $\begin{array}{ll}- & \text { İddialar çokludur ve deneysel veri ve } \\
& \text { gözlemlerin yorumlarıdır } \\
\text { - } & \text { İddialar araştırmanın özünü yakalar } \\
\text { • } & \text { İddialar geçerli ve yüksek kalitedir } \\
\end{array}$ \\
\hline 5 & $\begin{array}{ll} & \text { Birden fazla açık uçlu soru içeren çok soru } \\
\text { - } & \text { Testedilebilir sorulardır } \\
\text { - } & \text { Sorular tamamiyle araştırmanın özünü yakalar } \\
& \text { Sorular çok önemli ve yüksek kalitededir }\end{array}$ & $\begin{array}{ll} & \text { İddialar çokludur ve deneysel veri ve } \\
& \text { gözlemlerin yorumlarına dayalıdır } \\
\text { - } & \text { İddialar tamamiyle araştırmanın özünü yakalar } \\
\text { - } & \text { İddialar çok önemli ve yeterlidir } \\
\text { - } & \text { Idddialar çok geçerli ve yüksek kalitededir }\end{array}$ \\
\hline Puan & Sorular ve iddialar arasındaki ilişki & Delillerin kalitesi \\
\hline 1 & 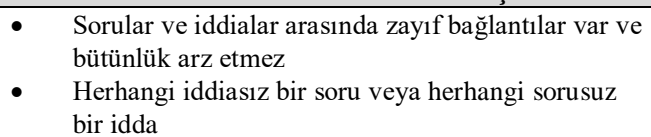 & $\begin{array}{l}\text { - Chok zayıf delil ve deliller güvenirsiz, geçersiz ve } \\
\text { doğrulanmaz } \\
\text { - Deliller çok seyrektir ve sadece gözlemlerdir. }\end{array}$ \\
\hline 2 & $\begin{array}{ll} & \text { Zayıf bağlantı, } \\
\text { - } & \text { Soru ve İddialar gevşek bir uyum içindedir } \\
\text { - } & \text { Öğrenci çok az soru için iddia geliştirir } \\
\text { - } & \text { İddialar soruları cevaplamada belirsizdir. }\end{array}$ & $\begin{array}{ll} & \text { Zayıf delil } \\
- & \text { Geçersiz ve doğrulanmayabilir } \\
- & \text { Delil verilerin tanımlanmasında yeterlidir } \\
\text { - } & \text { Delil ders kitabındandır }\end{array}$ \\
\hline 3 & $\begin{array}{ll} & \text { Orta düzeyde bağlantı } \\
\text { - } & \text { Soru ve iddialar oldukça uyum içindedir } \\
\text { - } & \text { Ögrenciler üretilen birkaç soru için iddia geliştirir } \\
& \text { ve belirtilen iddialar soruları cevaplamada uyumlu } \\
& \text { olabilir } \\
\text { - Iddalar tüm sorular üzerine odaklanır fakat } \\
\quad \text { sorularla gevşek bağlantı içindedir }\end{array}$ & $\begin{array}{l}\text { - } \quad \text { Orta düzeyde delil } \\
\text { - } \quad \text { Delil geçerli ve güvenilir olabilir } \\
\text { Delil sinırlı yorumlar, açıklamalarla ve ders } \\
\text { kitabıdır }\end{array}$ \\
\hline 4 & $\begin{array}{ll}- & \text { Güçlü bağlantı } \\
\text { - } & \text { Sorular ve iddialar güçlü bir şekilde bütünleşir } \\
\text { O Oğrenciler üretilen soruların pekçoğu için iddialar } \\
\text { geliştirir } \\
\text { - } \\
\text { Iddialar üretilen soruların birkaçı içindir sadece } \\
\text { buna rağmen belirtilen iddialar soruları } \\
\text { cevaplamada belirgindir }\end{array}$ & $\begin{array}{ll}- & \text { Güçlü delil } \\
-\quad & \text { Doğru, geçerli ve güvenilir delil } \\
\text { - } & \text { Deliller toplanılan gözlem ve verilerin } \\
& \text { yorumlarındandır }\end{array}$ \\
\hline 5 & $\begin{array}{ll} & \text { Çok güçlü bağlantı } \\
\text { - } & \text { Soru ve iddialar birlikteliği çok güçlüdür } \\
\text { - } & \text { Öğrenciler üretilen soruların tümü için iddialar } \\
& \text { geliştirir ve sağlanılan iddalar soruları } \\
& \text { cevaplamada çok açıktır }\end{array}$ & $\begin{array}{ll} & \text { Çok güçlü deliller } \\
\text { - } & \text { Cok doğru, geçerli ve zengin deliller } \\
\text { - } & \text { Çok sağlam ve güvenilir deliller } \\
\text { - } & \text { Deliller toplanılan gözlem ve verilerin } \\
& \text { yorumlarındandır }\end{array}$ \\
\hline Puan & İddialar ve deliller arasındaki ilişki & Çoklu temsiller \\
\hline 1 & $\begin{array}{ll} & \text { Iddialar ve delliler arasındaki bağlantı çok zayıf } \\
\text { - } & \text { Deliller hiçbir şekilde iddialar üzerine odaklanmaz } \\
\text { - } & \text { Iddiasız delil yâda delilsiz iddia } \\
\end{array}$ & $\begin{array}{ll} & \text { Tek modlu temsiller veya hiçbir temsil yok } \\
\text { - } & \text { Sadece metin }\end{array}$ \\
\hline 2 & $\begin{array}{ll}- & \text { Zayıf bağlantı } \\
\text { - } & \text { Deliller iddiaları yetersiz yada zayıf bir şekilde } \\
& \text { destekler } \\
\text { - } & \text { Öğrenciler birkaç iddia için delil sağlar } \\
\text { - } & \text { Deliller iddiaları desteklemede analaşılır değildir } \\
\text { - } & \begin{array}{l}\text { Delil birkaç iddia üzerine zayıf bir şekilde } \\
\text { odaklanır }\end{array} \\
\end{array}$ & $\begin{array}{ll}\text { - } & \text { İki modlu temsiller } \\
\text { - } & \text { Metin ve grafik } \\
\text { - } & \text { Metin ve matematiksel denklem } \\
\text { - } & \text { Metin ve kimyasal denklem } \\
& \text { diyagram }\end{array}$ \\
\hline 3 & $\begin{array}{ll} & \text { Orta düzeyde bağlantı } \\
\text { - } & \text { Deliller iddiaları oldukça destekler } \\
\text { - } & \text { Öğrenciler önerilen ve üretilen iddiaların bazıları } \\
& \text { için delil sağlarlar } \\
\end{array}$ & $\begin{array}{l}\text { - } \quad \text { Üç modlu temsiller } \\
\text { - } \quad \text { Üç tür temsil }\end{array}$ \\
\hline
\end{tabular}




\begin{tabular}{|c|c|c|}
\hline & $\begin{array}{ll}\text { - } & \text { Delil iddiaların tümü üzerine odaklanır fakat } \\
\text { iddalarla bağlantısı gevşektir }\end{array}$ & \\
\hline 4 & $\begin{array}{ll}\text { - } & \text { Güçlü bağlantı } \\
\text { - } & \text { Oelil güçlü bir şekilde iddiaları destekler } \\
& \text { sağlar } \\
\text { - } & \text { Deliller idddiaları güçlï bir şekilde destklemesine } \\
& \text { rağmen bazı iddalar hakkındadır } \\
\text { - } & \begin{array}{l}\text { Deliller tüm iddialar üzerine odaklanır ve iddalarla } \\
\text { güçlü bağlantıları verdır }\end{array} \\
\end{array}$ & $\begin{array}{ll}\text { - } & \text { Çeşitli modda temsiller } \\
\text { - } & \text { Dört tür temsil }\end{array}$ \\
\hline 5 & $\begin{array}{ll} & \text { Çok güçlü bağlantı } \\
\text { - } & \text { Deliller çok güçlü, etkili ve tamamiyle önerilen } \\
& \text { iddiaları destekler } \\
\text { - } & \text { Öğrenciler önerilen iddiaların tümü için delil } \\
& \text { sağlar } \\
\text { - } & \begin{array}{l}\text { Deliller iddiaların tümünü çok güçlü bir şekilde } \\
\text { destekler }\end{array} \\
\end{array}$ & $\begin{array}{l}\text { - } \quad \text { Çok moddlu temsil } \\
\text { - } \quad \text { Öş tür temsil } \\
\text { Orafik, tablo ve diyagram }\end{array}$ \\
\hline Puan & \multicolumn{2}{|l|}{$\begin{array}{ll} & \text { Yansıma } \\
\end{array}$} \\
\hline 1 & \multicolumn{2}{|c|}{$\begin{array}{ll} & \text { Fikirlerin niçin değişip yâda değişmediği açıklamaları çok zayıftır } \\
\text { - } & \text { Öğrenciler var olan bilgileriyle araştırmaları arasında bağlantı kuramazlar } \\
\text { - } & \text { Öğrenciler hataları fark etmezler } \\
\text { - } & \text { Öğrenci yeni sorulara sahip değildir }\end{array}$} \\
\hline 2 & \multicolumn{2}{|c|}{$\begin{array}{ll} & \text { Fikirlerin niçin değişip yâda değişmediği açıklamaları zayıftır } \\
\text { - } & \text { Öğrenciler var olan bilgileriyle araştırmaları arasında bağlantı kuramayabilirler } \\
\text { - } & \text { Öğrenci hataları farkedemeyebilir } \\
\text { - } & \text { Öğrenci yeni sorulara sahip olmayabilir } \\
\end{array}$} \\
\hline 3 & \multicolumn{2}{|c|}{$\begin{array}{ll}- & \text { Fikirlerin niçin değişip yâda değişmediğiyle ilgili orta düzeyde anlayış vardır } \\
\text { - } & \text { Öğrenciler sınıfta ögrendikleri şeylerle ilgili kavramları araştırmalarıyla nasıl bağlayacaklarını anlayabilir } \\
\text { - } & \text { Öğrenci kavramlar için bağlantı yapabilir } \\
\text { - } & \text { Öğrenci hataları ortaya çıkarır ama onları açıklayamaz } \\
\text { - } & \text { Öğrenci yeni sorulara sahip olabilir } \\
\end{array}$} \\
\hline 4 & \multicolumn{2}{|c|}{$\begin{array}{ll} & \text { Fikirlerin niçin değişip yâda değişmediğiyle ilgili güçlü anlayışları vardır } \\
\text { - } & \text { Öğgrenciler sınıfta ögrendikleri şeyler ilgili kavramları araştırmalarıyla nasıll bağlantılayacaklarını anlar } \\
\text { - } & \text { Öğrenci gerçek yaşam ve kavramlar arasında bazı bağlantılar kurar } \\
\text { - } & \text { Öğrenciler hataları ortaya çıkarır ve onlar hakkında bazı açılklamlara sahiptir } \\
\text { - } & \text { Öğrenci yeni sorulara sahiptir } \\
\end{array}$} \\
\hline 5 & \multicolumn{2}{|c|}{$\begin{array}{ll}\text { - } & \text { Fikirlerinin niçin değişip değişmediğini tamamiyle açıklar } \\
\text { - } & \text { Öğrenciler sınıfta öğrendikleri şeyler ilgili kavramları araştırmalarıyla nasıl bağlantılayacaklarını güçlü olarak } \\
& \text { anlar } \\
\text { - } & \text { Öğrenciler laboratuar çalışmalarıyla bağlantı kurmak için gerçek yaşam uyugulamalarından bazı örnekler tercih } \\
& \text { eder } \\
\text { - } & \text { Öğrenciler hatalarını doğrulamak için önerilere sahiptir } \\
\text { - } & \text { Öğrenciler düşünmek zorunda oldukları yeni şeylerin farkındadırlar } \\
\text { - } & \text { Öğrenciler araştırmayla ilgili testedilebilir yeni sorulara sahiptirler }\end{array}$} \\
\hline Puan & \multicolumn{2}{|c|}{ Bütünsellik } \\
\hline 2 & \multicolumn{2}{|c|}{$\begin{array}{ll} & \text { Çok zayıf tartışma } \\
\text { - } & \text { Tets edilemez sorular, geçersiz iddialar ve güvenilir olmayan deliller } \\
\text { - } & \text { Sorular, iddialar ve delliler arasında çok zayıf bağlantı } \\
\text { - } & \text { Bir alandan diğer bir alan kolayca geçmez } \\
\end{array}$} \\
\hline 4 & \multicolumn{2}{|c|}{$\begin{array}{ll}\text { - } & \text { Zayıf tartışma } \\
\text { - } & \text { Sorular testedilemez, geçersiz iddialar ve güvenilir olamayan delil } \\
\text { - } & \text { Yansitamaz } \\
\text { - } & \text { Sorular, iddialar ve deliller arasında zayıf bağlantı vardır } \\
& \text { Bir alandan diğer bir alana kolayca geçebilmez }\end{array}$} \\
\hline 6 & \multicolumn{2}{|c|}{$\begin{array}{ll}\text { - } & \text { Orta düzeyde bir tartışma } \\
\text { - } & \text { Sorular önemli olabilir, yeterli iddia, uygun delil ve yansıtma } \\
\text { - } & \text { Sorular, iddialar ve deliller arasında orta düzeyde bağlantı vardır } \\
\text { - } & \text { Bir alandan diğer bir alana kolayca geçebilir } \\
\end{array}$} \\
\hline 8 & \multicolumn{2}{|c|}{$\begin{array}{ll} & \text { Güçlü ve zenginleştirilmiş tartısma } \\
\text { - } & \text { Önmeli sorular, geçerli iddialar, güçlü deliller ve anlamlı yansımalar } \\
\text { - } & \text { Sorular, iddialar ve deliller arasında güçlü bağlantılar } \\
& \text { Bir alandan diğer bir alan geçiş iyidir }\end{array}$} \\
\hline 10 & \multicolumn{2}{|c|}{$\begin{array}{ll} & \text { Çok güçlü ve zenginleştirilmiş tartışma } \\
\text { - } & \text { Önemli sorular, çok sağlam iddialar, çok güçlü deliller ve çok anlamlı yansımalar } \\
\text { - } \quad & \text { Sorular, iddialar ve deliller arasında çok güçlü bağlantılar } \\
& \text { Bir alandan diğer bir alana geçiş çok iyidir } \\
\end{array}$} \\
\hline
\end{tabular}

(Choi, A. (2008). A Study of Student Written Argument Using The Science Writing Heuristic Approach in Inquiry-Based Freshman General Chemistry Laboratory Classes, May 2008, UMI Microform 3323405 Copyright 2008 by ProQuest LLC, tezinden uyarlanmıştır). 


\section{EXTENDED SUMMARY}

Introduction: Inquiry is centered on learning within science education reform studies in the last years and emphasizes that learner constructs his/her own knowledge. National Science Education Standards (NRC, 1996) states that inquiry based approach is a central component for learners to become active participants in their learning process and to use scientific thinking processes more effectively. Inquiry based science education as a way of improving learning process requires to think like scientists. This construction should reflect a change such as making claims based on evidence that directs scientific argumentation process and it is different from traditional teaching approach (Martin and Hand, 2009). The emphasis on scientific inquiry in science education presents the change based on argumentative and explanatory knowledge construction. From this perpective, the development of scientific knowledge is dependent on connecting inquiry targets and argumentation practice (Zembal-Saul, 2009). Argumentation is a scientific practice as a learning construction by thinking, writing and explaining, individually or in grops (Sampson, 2009). Argumentation Based Science Learning (ABSL) approach is based on inquiry to simplify learning in laboratory activities. It uses oral and written arguments and is a theoretic integration of writing and discourse (Hand ve Keys, 1999). In this respect, the aim of the study is to examine the development of argument structures in students' scientific reports in laboratory practice class.

Methodology: This study incorporates a process that states how prospective science teachers' qualitative statements in their laboratory reports can be evaluated in terms of quantitative data. The participants of the study were 46 prospective science teachers (Grade 2) in a state university in Turkey. The study is conducted in fall semester of 2012-2013 academic year. 25 male and 21 female students were participated. Students' written reports template which is used typically in Argumentation Based Science Learning approaches was used in order to collect the data. (Choi, 2008; Hand and Choi, ; Kıngir and others, 2011). When analyzing the data, a rating scale developed by Choi (2008) was benefited with the aim of converting the qualitative data into quantitative data (Appendix 1). The rating scale includes the constructs that underline argumentation components and the unity between these components. In the grading scale, every dimension enables evaluation between 1 to 5 points to represent properties of a particular number and qualification. t-test Statistical tecnique (in SPSS 17 programme) was used to analyze the data. The data were examined by the two researchers to be ensure of interval consistency.

Findings: The quality and scientific validity of Question, Claim and Argument component based on Argumentation Based Science Learning approach shows a significant development in five weeks and in the particular implementation topics. When analyzing prospective teachers' reports in terms of the relationship between Question- Claim, the mean value of the first activity (Different Cell Structure) is calculated as 1,32, the mean value of the second activity (Organic Matter Content) is calculated as 1,71, the mean value of the third activity (Cell Divisions) is calculated as 2,41, the mean value of the fourth activity (Blood Cells) is calculated as 2,91 and the mean value of the fifth activity (DNA isolation) is calculated as 3,32. When analyzing prospective teachers' reports in terms of the relationship between Claim- Argument, the mean value of the first activity (Different Cell Structure) is calculated as 1,17, the mean value of the second activity (Organic Matter Content) is calculated as 1,76, the mean value of the third activity (Cell Divisions) is calculated as 2,19 the mean value of the fourth activity (Blood Cells) is calculated as 2,80 and the mean value of the fifth activity (DNA isolation) is calculated as 3,21. The mean values of prospective teachers' integrated thinking construct are calculated as ; for the first activity (Different Cell Structure) 2,21, the second activity (Organic Matter Content) 3,82, the third activity (Cell Divisions) 5,34, the fourth activity (Blood Cells) 6,04 and the fifth activity (DNA isolation) 6,21. Depending on the these findings, prospective teachers' arguments based on the activity show a development in a five week time when evaluating them in means of integrated thinking construct.

Discussion: The study presents an analysis of writing reports based on Argumentation Based Science Learning approach is more effective than traditional laboratory reports on students' learning. The quality of the questions which lead to students' learning designs show a significant increase in every experiment procedure. It is important for students to investigate their own learning process in order to attain meaningful learning in science education. In this manner, it is an important stage for prospective teachers to construct the process by asking questions that will reveal their learning expectations (Hand and others, 2007). In the implementation, the qualitity of the Claim component in students' reports increases with the ongoing process. Cavagnetto and others (2009) evaluated the quality of the claim component as an important pedagogical stage in terms of the unity of inquiry based learning and the expactation towards the process in their study. There has been a development in the quality of students' questions and their claims based on the process. Researches related to argumentation based science learning indicate that students need strong evidence in order to support their claims (Choi, 2008). The research findings present using argumentation based science learning approach in laboratory practice contributes supporting students' meaningful learning and developing their conceptual undertanding (Hohenshell and Hand, 2006; Yore and others, 2003; Cronje and others, 2011). Integrating Argumentation Based Science Learning approach into the laboratory process is a new and interesting perspective which helps assimilation of scientific knowledge. 